\title{
Working
}

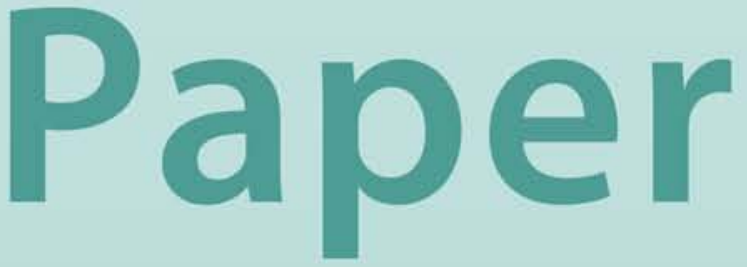




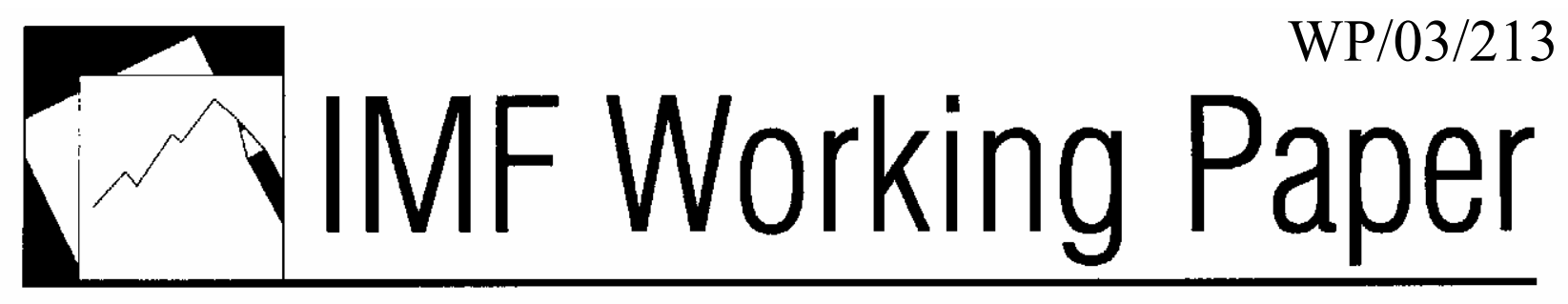

Early Birds, Late Risers, and Sleeping

Beauties: Bank Credit Growth to the

Private Sector in Central and Eastern

Europe and the Balkans

Carlo Cottarelli, Giovanni Dell'Ariccia, Ivanna Vladkova-Hollar 


\title{
IMF Working Paper
}

European Department

\section{Early Birds, Late Risers, and Sleeping Beauties: Bank Credit Growth to the Private Sector in Central and Eastern Europe and the Balkans}

\author{
Prepared by Carlo Cottarelli, Giovanni Dell'Ariccia, and Ivanna Vladkova-Hollar ${ }^{1}$
}

November 2003

\begin{abstract}
The views expressed in this Working Paper are those of the author(s) and do not necessarily represent those of the IMF or IMF policy. Working Papers describe research in progress by the author(s) and are published to elicit comments and to further debate.
\end{abstract}

Following a period of privatization and restructuring, commercial banks in Central and Eastern Europe and, more recently, in the Balkans have rapidly expanded their lending to the private sector. This paper describes the causes of this expansion, assesses future trends, and evaluates its policy implications. It concludes that bank credit to the private sector is likely to continue rising faster than GDP in the next few years throughout the region, picking up also in countries where so far it has been stalled. Although this growth should be regarded as a structural and positive development, policymakers will have to evaluate carefully its implications for macroeconomic developments and financial stability.

JEL Classification Number: E44, G21

Keywords: credit booms, financial developments, transition economies

Authors’ E-Mail Addressess: ccottarelli@imf.org, gdellariccia@imf.org, and ivladkovahollar@imf.org

\footnotetext{
${ }^{1}$ This paper was presented at the Ninth Dubrovnik Economic Conference, held in Dubrovnik, Croatia June 26-28, 2003. Carlo Cottarelli is a Senior Advisor in the IMF's European Department. Giovanni Dell'Ariccia is an Economist in the IMF's Research Department. Ivanna Vladkova-Hollar is an Economist in the IMF's Policy Development and Review Department. The paper has benefited from excellent research assistance provided by Jolanta Stefanska and comments from several members of the staff of the European Department and of the Offices of the Executive Directors of the IMF. We thank Abdul Abiad for providing the financial liberalization indices and Gian Maria Milesi-Ferretti for providing the public debt data used in Appendix II.
} 


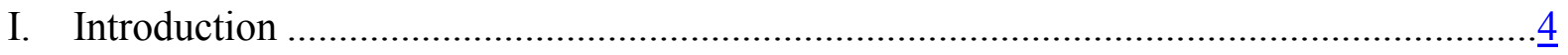

II. Bank Credit Growth and Shifts in Banks' Balance Sheets: Stylized Facts.........................

III. Reasons for These Trends and Assessment of Future Trends .....................................14

A. Lessons From the Past............................................................................ $\frac{19}{23}$

B. The Outlook for BCPS Growth: Microeconomic Factors.....................................

C. The Outlook for BCPS Growth: Macroeconomic Factors .....................................

IV. Macroeconomic Implications of Fast Bank Credit Growth.........................................35

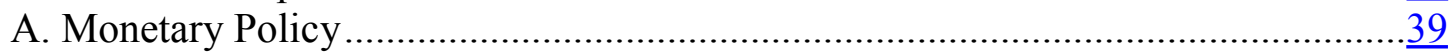

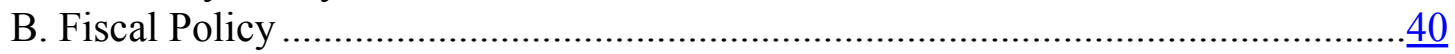

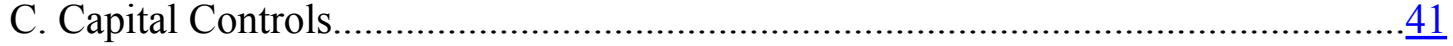

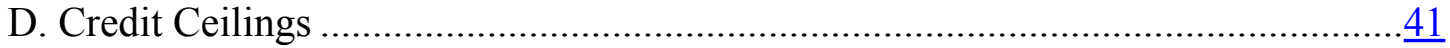

E. Prudential Instruments.........................................................................

V. Fast Credit Growth and Financial Stability........................................................ 43

A. Lending Booms and Banking Crises: A Brief Review of the Literature ................44

B. Detecting Lending Booms in CEB Countries ..............................................

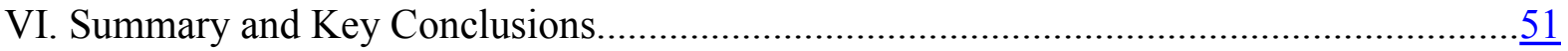

Appendixes

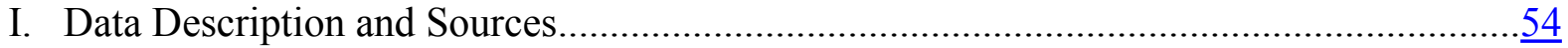

II. Econometric Model: Specification..................................................................... 57

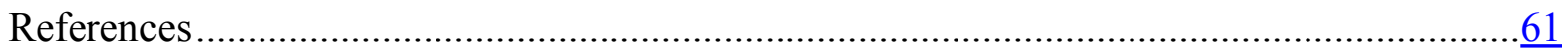

Text Tables

1. Bank Assets and Stock Market Capitalization............................................................ $\underline{6}$

2. Measure of Growth of Bank Credit to the Private Sector (BCPS) .................................. $\underline{8}$

3. Financing the Growth of the BCPS Ratio: Changes in the Ratio Between

Balance Sheet Items and GDP

4. Financing the Growth of the BCPS Ratio: Annual Average Changes in the

Ratio Between Balance Sheet Items and GDP

5. Bank Credit to the Private Sector: Annual Real Growth Rates, by Economic

Sector, 1998-2001 
6. Factors Affecting Bank Credit Growth: Does Initial Size Matter?

Does Fiscal Policy Matter?

7. Factors Affecting Bank Credit Growth: The Role of the Transition

Process

8. Factors Affecting Bank Credit Growth: Privatization and

Foreign Ownership

.24

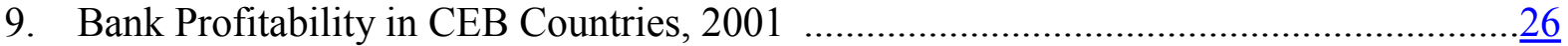

10. Subjective Assessment of Factors Preventing Faster Bank Credit Growth

to the Private Sector

11. Per Capita Income and BCPS Ratios in the Euro Area and in

CEB Countries

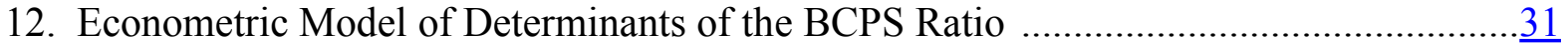

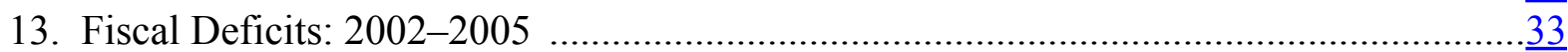

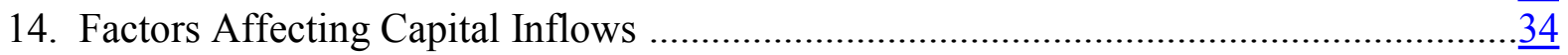

15. Controls on Capital Inflows, Excluding Real Estate Purchases ..................................42

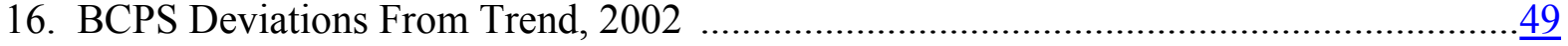

17. BCH Deviations From Trend, 2002 …................................................................... $\frac{50}{50}$

18. Hungary: Deviations of BCH Ratio from Rolling Trend .......................................... $\underline{50}$

Figures

1. Bank Credit to the Private Sector-to-GDP Ratios in Central and Eastern

European and Balkan (CEB) Countries ....................................................................... 11

2. Change in Credit-to-GDP Ratio by Sector 1997-2002 ...............................................18

3. Bank Credit to Private Sector-to-GDP Ratio and Purchasing Power

Parity (PPP) Per Capita Income, 2001

4. Private Sector Credit, Real Interest Rates, and External Current Account

Before Euro's Adoption $\underline{38}$

5. BCPS Ratios in Bank Crisis Countries and Early Birds 


\section{INTRODUCTION}

Strong growth in bank credit to the private sector (BCPS) has been a feature of several transition economies in Central and Eastern Europe since the second half of the 1990s. For example, the cumulative growth of BCPS in real terms in Bulgaria, Estonia, and Latvia was, respectively, 315, 121, and 304 percent during 1998-2002. While these rates are inflated by the initially low levels of credit stocks, the BCPS-to-GDP ratio (hereinafter referred to as the BCPS ratio) also increased fast (by 11, 22, and 17 percentage points, respectively, for the same three countries and period). More recently, BCPS has also accelerated in some Balkan countries where the transition process is less advanced. In 2002, BCPS in real terms rose by over 50 percent in Bosnia and Herzegovina $(\mathrm{BiH})$ and by 23 percent in Serbia and Montenegro (SM). In the same year these two countries experienced sharp rises in their external current account deficits, which were attributed, at least in part, to the surge in bank credit. $^{2}$

The macroeconomic and macroprudential implications of strong credit growth in nonEuropean emerging economies have attracted considerable attention, particularly after the Asian crisis of the late 1990s. However, credit developments in Central and Eastern Europe and in the Balkans (hereinafter referred to as CEB) have not been studied extensively. This is part due to the fact that credit growth in this area has not yet reached the excessive rates seen in some Asian countries during the 1990s, and in any case has not yet led to major macroeconomic imbalances. Credit growth in the CEB area is likely to remain strong or, indeed, accelerate in the years ahead, reflecting

(i) a natural tendency of financial systems in these countries to deepen; and (ii) the likelihood of strong capital inflows, partly through the banking system, in the context of large differences in capital/labor ratios with respect to Western Europe, expectations of real exchange rate appreciation, and still-sizable nominal interest rates differentials.

Against this background, this paper

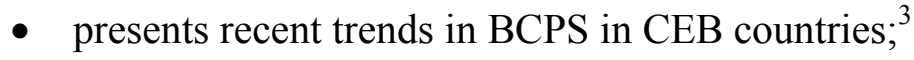

- evaluates the factors affecting these trends, the differences across countries, and the likely trends over the coming years. In this context - and as a tool to assess where CEB

${ }^{2}$ See, for example, IMF Press Release No. 03/81 of June 6, 2003, relative to Bosnia and Herzegovina.

${ }^{3}$ Our country group includes 15 countries: Albania, Bosnia and Herzegovina (BiH), Bulgaria, Croatia, the Czech Republic, Estonia, Hungary, Latvia, Lithuania, the Former Yugoslav Republic of Macedonia, Poland, Romania, Serbia and Montenegro (SM), the Slovak Republic, and Slovenia. 
countries stand with respect to similar economies and to anticipate trends in bank credit growth - we also present estimates of an econometric model of the structural determinants of the BCPS ratio, an important issue which so far has not been fully explored;

- assesses the implications of fast credit growth (and, more specifically, of a rising BCPS ratio) for macroeconomic developments and policies, with specific reference to countries, like the CEB countries, where the growth of bank markets is likely to be coupled with strong capital inflows through the banking system; and

- discusses the effects of strong credit growth on financial stability, taking into account not only the growth of BCPS but also its sectoral composition.

These four topics are discussed in Sections II-V. Section VI summarizes the paper's conclusions.

\section{Bank Credit Growth and Shifts in Banks' Balance Sheets: Stylized Facts}

A distinguishing feature of CEB countries is that they all have recently gone through a process of transformation from socialist to market economic structures and institutions. ${ }^{4}$ This transition process involved a deep transformation in the role played by commercial banks. In most cases, CEB banking systems went through three phases: (i) the recognition that a large share of the loans extended by public banks, mostly to state enterprises, had to be written off and the shift to the government of the related loss, $;^{5}$ (ii) the sale of banks, primarily to foreign investors; and (iii) the beginning of more standard banking operations, including increased lending to truly private enterprises. The timing of this process varied across countries, in line with the pace of transformation of banking institutions and structures. But this sequencing was a fairly common feature in all CEB countries.

A second feature of CEB countries is that, similarly to other European countries, their financial system is centered on banks. In most CEB countries the share of bank assets over total assets held by financial institutions (banks, insurance companies, pension funds, securities firms, investment funds, leasing companies) exceeds 85 percent (Table 1).

\footnotetext{
${ }^{4} \mathrm{CEB}$ countries are often referred to as "transition countries." We prefer a geographical expression as, by now, the transition process is virtually completed in terms of legal structures and institutions in several CEB countries. It should be stressed, however, that even if the transition process may have been completed in these terms, the actual convergence process, in terms of economic behaviors and outcomes, is likely to take several more years. For example, and with reference to the focus of this paper, even when the transition to a legal and institutional market framework has been completed, it takes inevitably time before credit markets fully develop.

${ }^{5}$ In some countries the outstanding stock of loans was simply written off by high inflation.
} 
Table 1. Bank Assets and Stock Market Capitalization

\begin{tabular}{|c|c|c|c|}
\hline & \multicolumn{2}{|c|}{$\begin{array}{r}\text { Bank Assets (In percent of assets of all } \\
\text { financial intermediaries) }^{1} \\
\end{array}$} & $\begin{array}{l}\text { Stock Market Capitalization } \\
\text { (In percent of GDP) }\end{array}$ \\
\hline Albania 98.1 & & (2002) & 0.0 \\
\hline Bosnia and Herzegovina & 88.0 & (2002) & 4.8 \\
\hline Bulgaria 86.6 & & (June 2001) & 3.7 \\
\hline Croatia 91.9 & & (June 2001) & 16.8 \\
\hline Czech Republic & 85.3 & (2001) & 15.4 \\
\hline Estonia 84.3 & & (1999) & 27.0 \\
\hline Hungary 75.1 & & (September 2001) & 18.7 \\
\hline Latvia 90.7 & & (2000) & 9.2 \\
\hline Lithuania 86.5 & & (2001) & 10.0 \\
\hline Macedonia, FYR & n.a. & & 2.0 \\
\hline Poland 85.3 & & (2001) & 14.0 \\
\hline Romania 91.7 & & (2000) & 6.0 \\
\hline Serbia and Montenegro & 87.5 & (2002) & 3.1 \\
\hline Slovak Republic & 87.7 & (2001) & 3.3 \\
\hline Slovenia 74.3 & & (2001) & 15.3 \\
\hline
\end{tabular}

Sources: EBRD (2002); and IMF staff calculations based on data in Thimann (2002) and data provided by country authorities.

${ }^{1 /}$ The figures refer to the end of the year reported in parenthesis (unless otherwise indicated).

${ }^{2 /}$ Figures are as of the end of 2001, except Serbia and Montenegro (May 2003). As a reference, stock market capitalization, on average, exceeded 70 percent in the euro area at the end of 2001.

Moreover, equity markets are also small (Table 1). ${ }^{6}$ Thus, bank credit is by far the most important channel of external financing to private firms.

Reflecting these two features, in recent years the stock of BCPS in CEB countries has started to rise from fairly low levels in line with the developments of private sector activity and institutions. The speed of increase, as well as the way the increase was financed, have, however, varied sharply within the area (Tables 2-4 and Figure 1$).{ }^{7}$ Broadly speaking, we identify three country groups:

\footnotetext{
${ }^{6}$ The sale of private securities issued by nonfinancial enterprises directly to savers is also very modest (Köke and Schröder, 2002; Pissarides, 2001).

${ }^{7}$ In these tables, as well as in the rest of the paper, the data on BCPS refer to loans extended by commercial banks to households and nonbank private enterprises (see Appendix I on data
} 
The seven "early birds." In seven countries (Bulgaria, Croatia, Estonia, Hungary, Latvia, Poland, and Slovenia) the BCPS ratio has been rising for at least five years at an annual average rate exceeding $1 \frac{1}{2}$ percentage point of GDP, with peaks of almost $4 \frac{1}{2}$ percentage points in Estonia (Table 2). These countries also share a fairly similar experience in the way the increase in BCPS was financed (Tables 3-4). In all of them, the increase reflected in part increased bank intermediation (as highlighted by a rising deposit-toGDP ratio); and in all but one it also reflected a decline in bank credit to the government sector-to-GDP ratio. Indeed, in some countries - Bulgaria, Croatia, and Hungary - the increase in bank deposits and the decline in credit to the government also allowed banks to improve their net asset position with the rest of the world. Thus, at least in these cases, the expansion of BCPS was not constrained by the availability of domestic funds. However, in other countries - Estonia, Latvia, Poland, and Slovenia - the rise in the BCPS ratio was also supported by increased net borrowing from abroad

The three "late risers." Three countries (Bosnia and Herzegovina, Lithuania, and Serbia and Montenegro) have experienced only recently a rise in the BCPS ratio exceeding $1 \frac{1}{2}$ percentage points of GDP per year (Table 2 ). The rise was fueled by a surge in deposits that, in the case of $\mathrm{BiH}$, also allowed banks to improve their net asset position with the rest of the world. In $\mathrm{BiH}$ and $\mathrm{SM}$ this surge (which involved also countries of the other two groups, such as Croatia) reflected the response of bank customers to the introduction of the euro. The latter forced holders of pre-euro currency notes to deposit them in banks in order to convert them into euros. The bulk of these resources stayed in the banking system. Thus, the introduction of the euro caused a permanent shift in the distribution of agents' holdings of cash versus deposits, which provided the resources for banks to expand their loans. Of

sources). Bank loans to public enterprises are instead treated as credit to the government sector. However, for some countries for which the breakdown was not available (Czech Republic, SM, Slovenia), the BCPS series also include public enterprises. Partly for this reason, we focus on comparing the growth rate of BCPS across countries, rather than on levels. However, growth rates may also be affected if the share of credit to public enterprises over total bank credit changed during the period. Note also that the BCPS ratio is also affected by write-offs of bad loans. Indeed, as noted, this is the reason why BCPS ratios decline in the early years of our sample. However, in assessing developments we usually focus on the period following major write-offs operations (as in the case of SM, for example, where we focus on 2002). Even when this is not the case (for example, in Albania write-off operations reduced the BCPS ratio by some 1 percent of GDP in 2001-2002), the classification of countries in the three groups used in this paper is not fundamentally affected. 
Table 2. Measures of Growth of Bank Credit to the Private Sector (BCPS)

\begin{tabular}{|c|c|c|c|c|}
\hline & Turning Point ${ }^{1}$ & $\begin{array}{c}\text { Average Annual } \\
\text { Real Growth } \\
\text { Rate }^{23}\end{array}$ & $\begin{array}{c}\text { Change in } \\
\text { BCPS Ratio }^{2}\end{array}$ & $\begin{array}{c}\text { Average Annual } \\
\text { Change in BCPS } \\
\text { Ratio }^{2}\end{array}$ \\
\hline \multicolumn{5}{|l|}{ Early birds } \\
\hline Bulgaria & 199833.0 & & 11.0 & 2.2 \\
\hline Croatia & 199412.3 & & 20.8 & 2.6 \\
\hline Estonia & 199425.9 & & 35.3 & 4.4 \\
\hline Hungary & 1997 & 11.1 & 9.2 & 1.5 \\
\hline Latvia & 199731.4 & & 17.9 & 3.0 \\
\hline Poland & 199613.5 & & 12.9 & 1.8 \\
\hline Slovenia & 199213.0 & & 21.6 & 2.2 \\
\hline \multicolumn{5}{|l|}{ Late risers } \\
\hline Bosnia and Herzegovina & 2001 & 36.6 & 9.2 & 4.6 \\
\hline Serbia and Montenegro & 2002 & 23.1 & 2.3 & 2.3 \\
\hline Lithuania & 200223.7 & & 2.6 & 2.6 \\
\hline \multicolumn{5}{|l|}{ Sleeping beauties } \\
\hline Albania & -- & 14.5 & 1.5 & 0.3 \\
\hline Czech Republic & -- & 4.4 & -15.0 & -3.0 \\
\hline Macedonia, FYR & -- & -6.7 & -9.1 & -1.8 \\
\hline Romania & -- & 4.7 & 1.3 & 0.3 \\
\hline Slovak Republic & -- & 6.7 & -20.1 & -4.0 \\
\hline
\end{tabular}

Source: Appendix I.

${ }^{1}$ Year when the BCPS-to-GDP ratio starts rising in counties where, thereafter, the average rise in the ratio as of that year has been at least 1.5 percentage points per year. If the BCPS ratio has been rising steadily (except for at most one year), the turning point is the first year for which the series is available, and the growth rates and charges in the BCPS ratio are computed from that year.

${ }^{2}$ As of the turning point or during 1998-2002. The BCPS data are geometric averages of beginning-of-the-year and end-of-the year stocks.

${ }^{3}$ Credit growth is deflated by the GDP deflator. 
Table 3. Financing the Growth of the BCPS Ratio: Changes in the Ratio Between Balance Sheet Items and GDP (In percentage points of GDP $)^{1}$

\begin{tabular}{|c|c|c|c|c|c|c|}
\hline $\mathrm{R}$ & $\begin{array}{l}\text { eference } \\
\text { Period }\end{array}$ & $\begin{array}{l}\text { Bank Loans to } \\
\text { Private Sector }\end{array}$ & $\begin{array}{l}\text { Bank Credit to } \\
\text { the Public Sector }\end{array}$ & $\begin{array}{c}\text { Bank } \\
\text { Deposits }\end{array}$ & $\begin{array}{l}\text { Net Foreign } \\
\text { Liabilities }\end{array}$ & $\begin{array}{l}\text { Other Net } \\
\text { Liabilities }\end{array}$ \\
\hline \multicolumn{7}{|l|}{ Early birds } \\
\hline Bulgaria & 1998-2002 & 11.0 & -5.9 & 14.0 & -6.4 & -2.5 \\
\hline Croatia & 1995-2002 & 20.8 & -11.4 & 30.0 & -7.7 & $-12.9^{2}$ \\
\hline Estonia & 1992-2002 & 35.2 & -0.2 & 19.0 & 9.9 & 6.2 \\
\hline Hungary & 1997-2002 & 9.2 & -1.9 & 2.1 & -3.9 & $9.1^{3}$ \\
\hline Latvia & 1998-2002 & 16.7 & 0.2 & 11.1 & 10.3 & -4.4 \\
\hline Poland & 1998-2002 & 9.1 & -1.2 & 9.6 & 2.6 & -4.3 \\
\hline Slovenia & 1995-2002 & 18.6 & -0.4 & 18.3 & 2.4 & -2.6 \\
\hline \multicolumn{7}{|l|}{ Late risers } \\
\hline Bosnia and Herzegovina & $2001-2002$ & 9.2 & -5.2 & 12.1 & -4.4 & -3.7 \\
\hline Serbia and Montenegro & $2002^{4}$ & 2.3 & 0.1 & 3.9 & 0.6 & $-2.2^{5}$ \\
\hline Lithuania & 2002 & 2.6 & 0.6 & 2.3 & 1.2 & -0.2 \\
\hline \multicolumn{7}{|l|}{ Sleeping beauties } \\
\hline Albania & 1998-2002 & 1.4 & -9.7 & 3.3 & -0.2 & $-11.4^{6}$ \\
\hline Czech Republic & 1998-2002 & -14.9 & 8.7 & -1.3 & 19.2 & $-24.2^{7}$ \\
\hline Macedonia, FYR & 1998-2002 & -9.1 & 1.6 & 15.5 & -8.7 & $-14.3^{8}$ \\
\hline Romania & 1998-2002 & 1.3 & -4.3 & -1.6 & -0.2 & -1.2 \\
\hline Slovak Republic & 1998-2002 & -20.2 & 10.2 & 1.8 & 5.1 & $-16.7^{9}$ \\
\hline
\end{tabular}

Source: Appendix I.

${ }^{1}$ Each entry shows the change in the ratio between the corresponding balance sheet item and GDP during the reference period. The reference period starts, for early birds and late risers, with the turning point year (or the year after the turning point for countries where the latter coincides with the beginning of the balance sheet series; see Table 2). For the sleeping beauties, the period covers the last five years ending in 2002. The balance sheet data are geometric averages of beginning-of-the-year and end-of-the-year stocks. The changes in the credit to the private sector ratio may differ slightly from those reported in Table 2 due to rounding; for Latvia, Poland, and Slovenia the change in this table is computed for a shorter time period due to unavailability of a longer (and consistent) time series for all balance sheet items.

${ }^{2}$ About half of this sharp decline in other net liabilities reflects increased assets of commercial banks held at the central bank. The latter partly reflects sterilized intervention by the central bank and, partly, the increase in required reserves over GDP (in line with the rise in the deposit to GDP ratio).

${ }^{3}$ The bulk of this net increase in liabilities reflects the fall in net assets held at the central bank between 1999 and 2001 owing to large declines in reserve requirements.

${ }^{4}$ The data refer to the banks existing at end 2002 and, thus, exclude the four large state banks which were closed in early 2002.

${ }^{5}$ This decline reflects a 50 percent liquidity requirement (increase in assets) imposed by the central bank.

${ }^{6}$ This sharp decline in net liabilities reflects the sharp drop in government deposits at commercial banks. This is broadly matched by the decline in credit to the government.

${ }^{7}$ The large drop in other net liabilities results from the surge in assets of commercial banks at the central bank, reflecting large sterilization operations.

${ }^{8}$ This decline reflects the cancellation in September 1998 of accrued interest on bank loans.

${ }^{9}$ The drop in other net liabilities reflects the increase in assets held at the central bank, due to large sterilization operations. 
Table 4. Financing the Growth of the BCPS Ratio: Annual Average Changes in the Ratio Between Balance Sheet Items and GDP (In percentage points of GDP) ${ }^{1}$

\begin{tabular}{|c|c|c|c|c|c|c|}
\hline $\mathrm{R}$ & $\begin{array}{l}\text { eference } \\
\text { Period }\end{array}$ & $\begin{array}{l}\text { Bank Loans to } \\
\text { Private Sector }\end{array}$ & $\begin{array}{l}\text { Bank Credit to } \\
\text { the Public Sector }\end{array}$ & $\begin{array}{c}\text { Bank } \\
\text { Deposits }\end{array}$ & $\begin{array}{l}\text { Net Foreign } \\
\text { Liabilities }\end{array}$ & $\begin{array}{l}\text { Other Net } \\
\text { Liabilities }\end{array}$ \\
\hline \multicolumn{7}{|l|}{ Early birds } \\
\hline Bulgaria & $1998-2002$ & 2.2 & -1.2 & 2.8 & -1.3 & -0.1 \\
\hline Croatia & $1995-2002$ & 2.6 & -1.4 & 3.8 & -1.0 & -1.6 \\
\hline Estonia & 1992-2002 & 3.2 & -0.0 & 1.7 & 0.9 & 0.6 \\
\hline Hungary & 1997-2002 & 1.5 & -0.3 & 0.4 & -0.7 & 1.5 \\
\hline Latvia & $1998-2002$ & 3.3 & 0.0 & 2.2 & 2.1 & -1.0 \\
\hline Poland & $1998-2002$ & 1.8 & -0.2 & 1.9 & 0.5 & -1.0 \\
\hline Slovenia & $1995-2002$ & 2.3 & -0.1 & 2.2 & 0.5 & -0.3 \\
\hline Average & & 2.4 & -0.4 & 2.2 & 0.1 & -0.3 \\
\hline \multicolumn{7}{|l|}{ Late risers } \\
\hline Bosnia and Herzegovina & 2001 & 4.6 & -2.6 & 6.1 & -2.2 & -1.9 \\
\hline Serbia and Montenegro & 2002 & 2.3 & 0.1 & 3.9 & 0.6 & -2.2 \\
\hline Lithuania & 2002 & 2.6 & 0.6 & 2.3 & 1.2 & -0.2 \\
\hline Average & & 3.2 & -0.6 & 4.1 & -0.1 & -1.4 \\
\hline \multicolumn{7}{|l|}{ Sleeping beauties } \\
\hline Albania & 1998-2002 & 0.3 & -1.9 & 0.7 & -0.0 & -2.3 \\
\hline Czech Republic & 1998-2002 & -3.0 & 1.7 & -0.3 & 3.8 & -4.8 \\
\hline Macedonia, FYR & 1998-2002 & -1.8 & 0.3 & 3.1 & -1.7 & -2.9 \\
\hline Romania & $1998-2002$ & 0.3 & -0.9 & -0.3 & -0.0 & -0.2 \\
\hline Slovak Republic & $1998-2002$ & -4.0 & 2.0 & 0.3 & 1.0 & -3.3 \\
\hline Average & & -1.6 & 0.2 & 0.7 & 0.6 & -2.7 \\
\hline
\end{tabular}

Source: Appendix I.

${ }^{1}$ This table is derived from Table 3a by dividing the overall changes by the numbers of years in the reference period. 
Figure 1. Bank Credit to the Private Sector-to-GDP Ratios in Central and Eastern European and Balkan (CEB) Countries

(Percentage points)

\section{Late Risers}
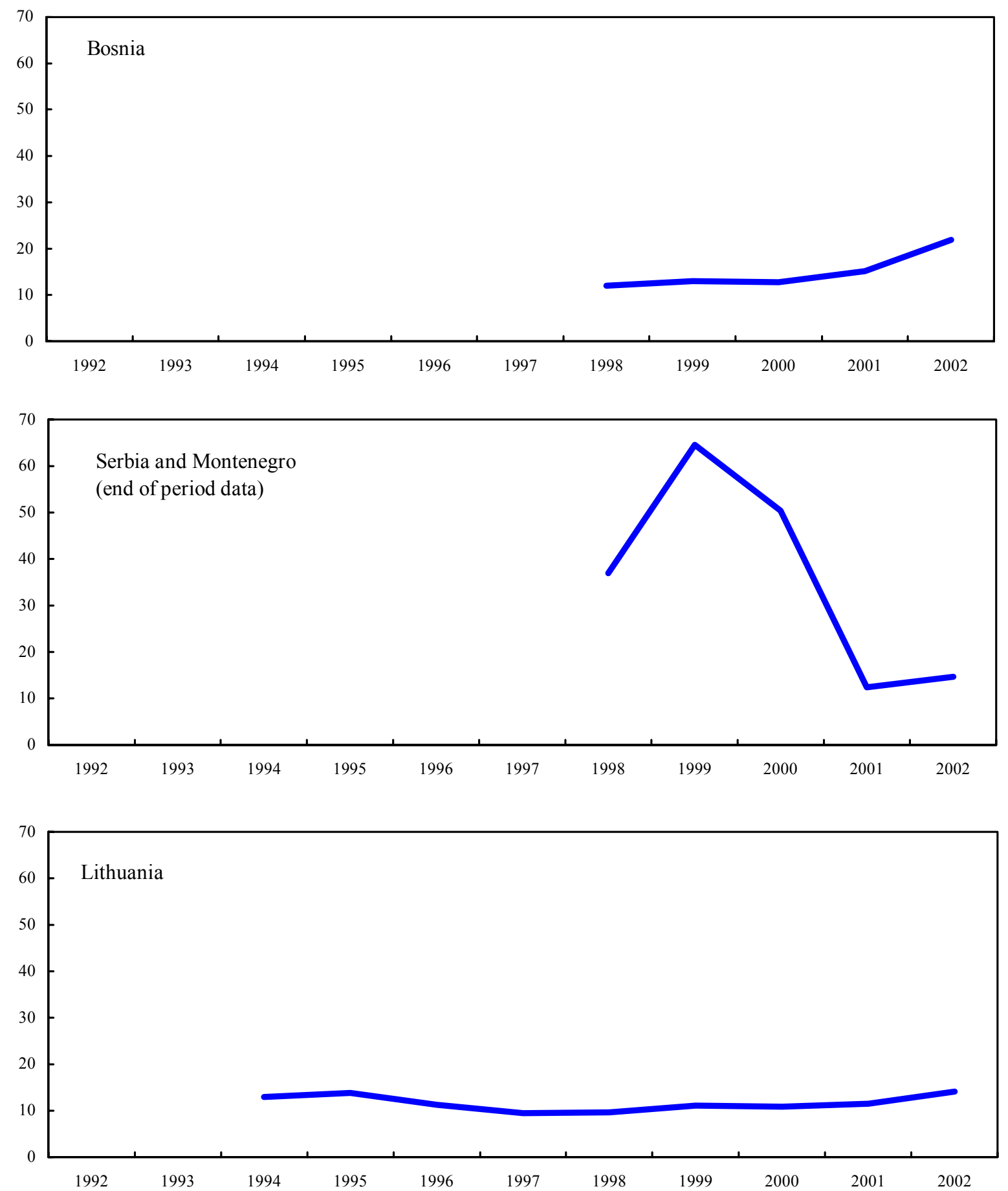
Figure 1 (continued). Bank Credit to the Private Sector-to-GDP Ratios in CEB Countries (Percentage points)

Sleeping Beauties

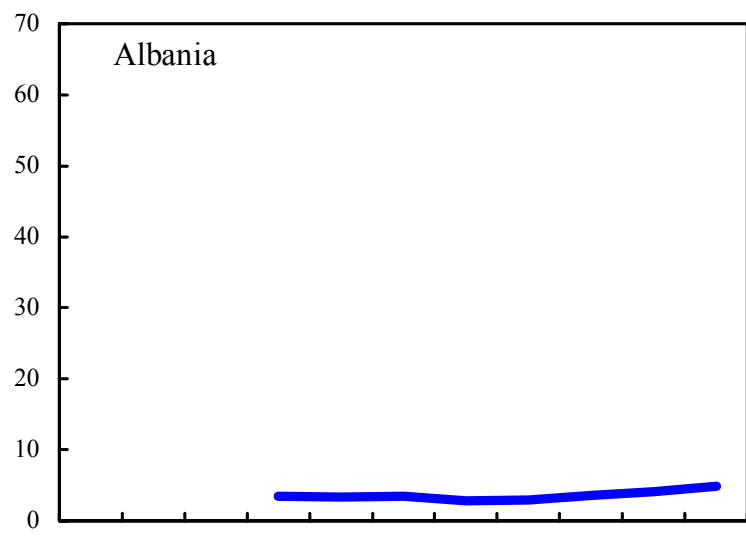

19921993199419951996199719981999200020012002
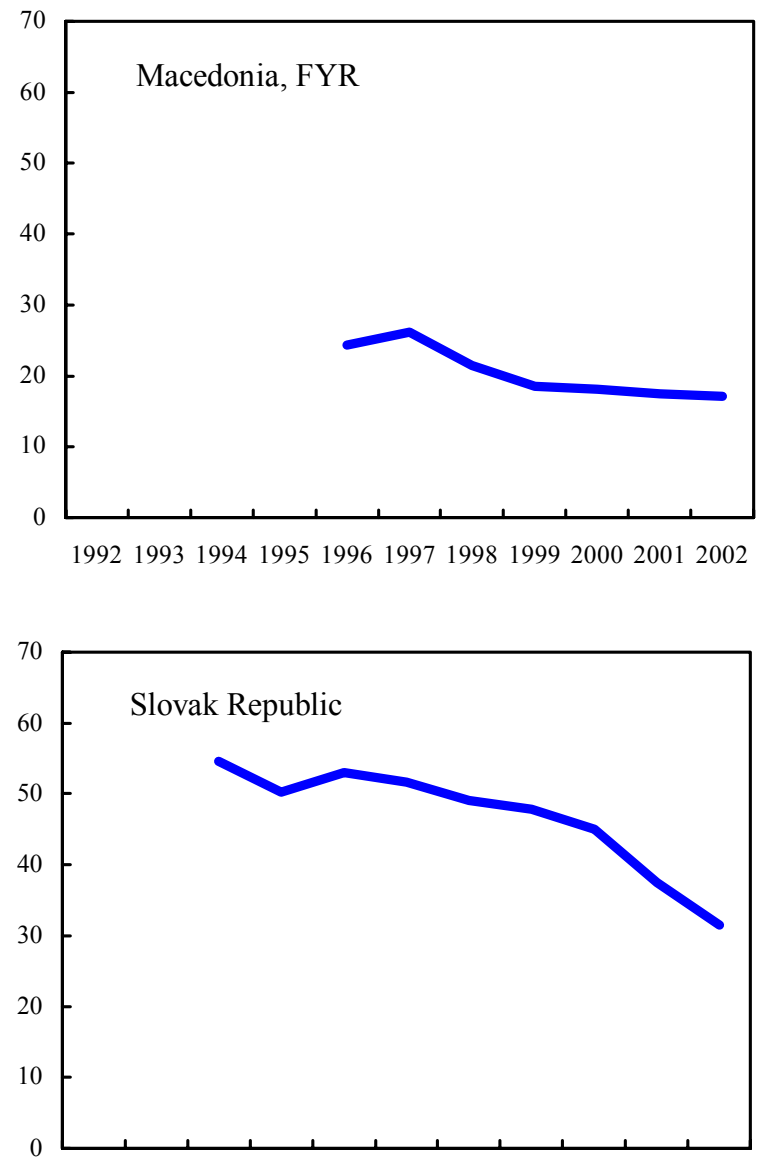

19921993199419951996199719981999200020012002
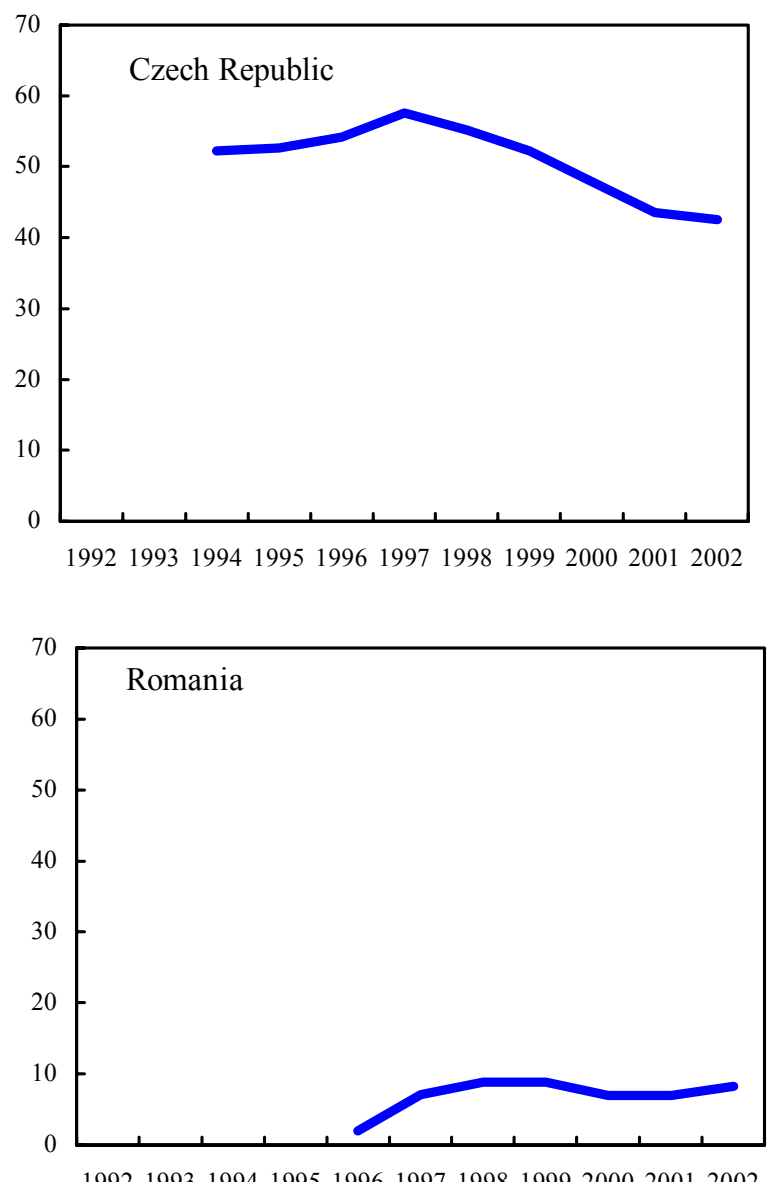

19921993199419951996199719981999200020012002 
Figure 1 (concluded). Bank Credit to the Private Sector-to-GDP Ratios in CEB Countries (Percentage points)

\section{Early Birds}

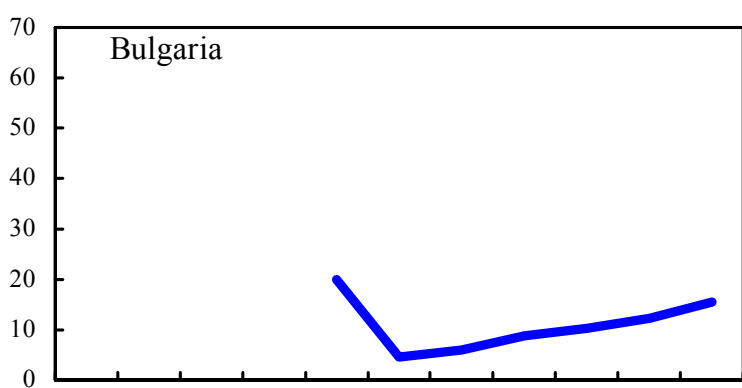

19921993199419951996199719981999200020012002

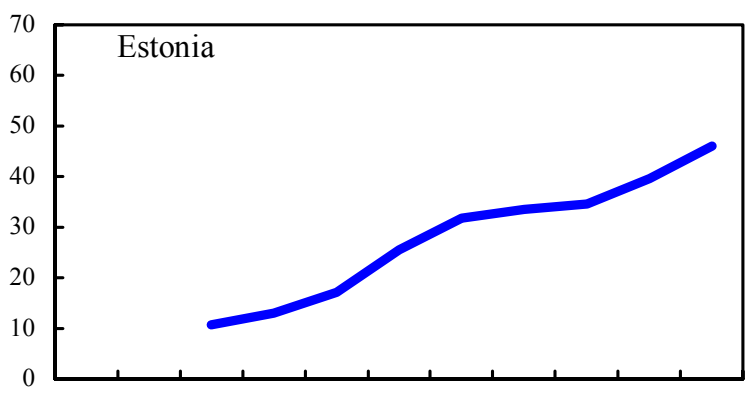

19921993199419951996199719981999200020012002

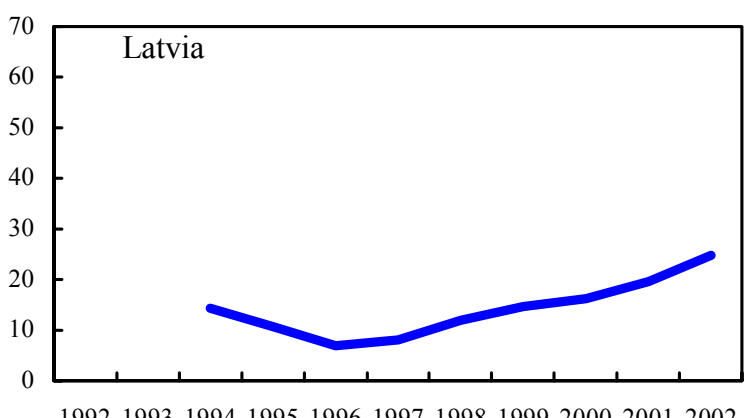

19921993199419951996199719981999200020012002

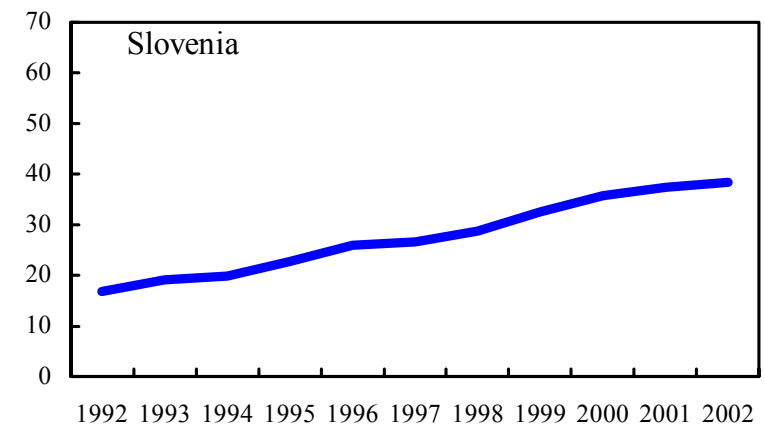

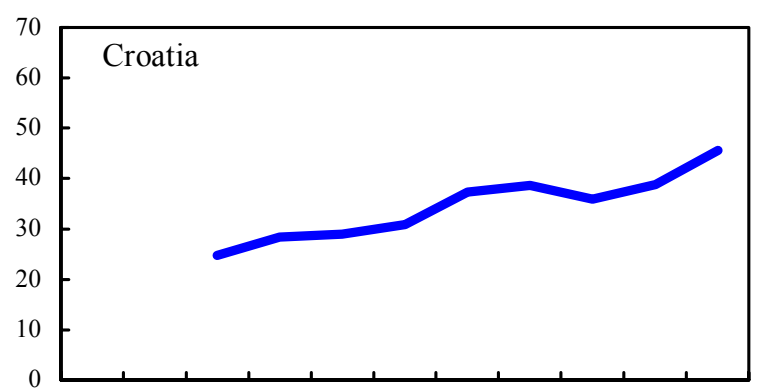

19921993199419951996199719981999200020012002

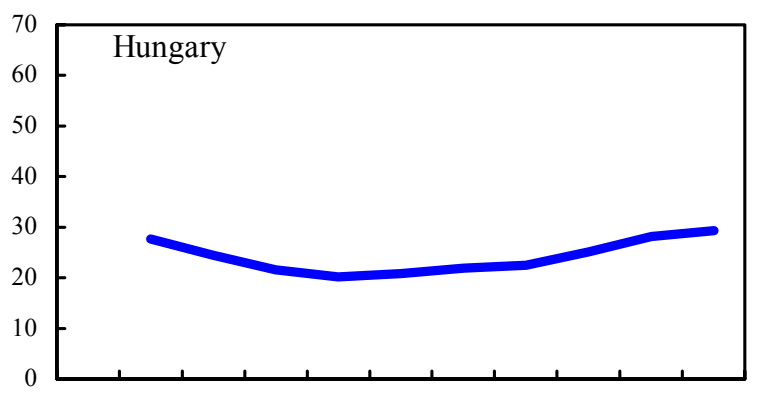

19921993199419951996199719981999200020012002

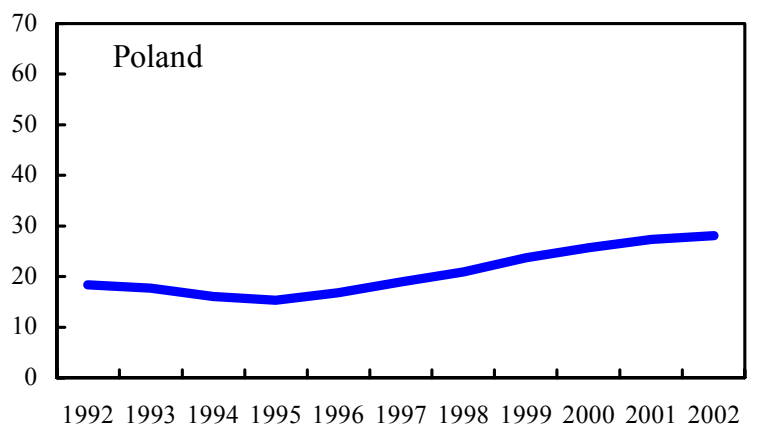


course, it remains to be seen whether the recent acceleration of BCPS in these countries reflects a change in trend rather than a temporary phenomenon.

The five "sleeping beauties." In the remaining five countries (Albania, Czech Republic, the Former Yugoslav Republic of Macedonia, Romania, and Slovakia), the BCPS ratio, after an initial decline (partly reflecting writing-off operations) has, in recent years, broadly stabilized (except in the Slovak republic where a sizable decline was observed also in 2002). More generally, bank balance sheets in most of these countries seem to have expanded in line with GDP with limited changes in balance sheet composition (Tables 3-4). ${ }^{8}$ However, behind this apparent dullness, two developments have taken place. First, in some countries - Czech Republic, FYR Macedonia, and Slovak Republic - while overall growth in bank loans has not exceeded that of GDP, credit to households has increased more rapidly (Table 5, and next paragraph). Second, in some sleeping beauties (e.g., Romania) the growth of BCPS has recently largely exceeded that of GDP (Table 5), although the increase remains fairly small in percentage of GDP owing to the initially low level of the credit stock. In these counties, while the macroeconomic effect of high BCPS growth may still be contained, the prudential supervision implications arising from a high growth rate will have to be closely examined.

Looking at credit data disaggregated by sector of destination confirms our grouping of CEB countries in "early birds" and "sleeping beauties." (Figure 2) Between 1997 and 2002, in all early birds, both credit to households and credit to corporates increased relative to GDP, although to different extents. Instead, credit to the corporate sector declined relative to GDP in three out of four sleeping beauties for which such decomposition was possible, and it $1 \frac{1 / 2}{2}$ remained virtually constant in Romania. At the same time, these countries also experienced a lower growth in credit to households relative to the early birds. This evidence suggests that institutional elements and factors originating in the banking system, rather than in the borrowing sectors were responsible for the differences between the sleeping beauties and the early birds.

\section{REASOnS FOR THESE TRENDS AND ASSESSMENT OF FUTURE TrENDS}

What factors supported BCPS growth and why has BCPS growth differed across countries? And what lies ahead? Will the BCPS ratio continue to rise in the early birds and late risers groups? And when will the ratio pick up in the sleeping beauties? The different behavior of the BCPS ratio across countries is likely to reflect a number of causes, the relative importance of which could in principle be assessed through econometric analysis. In practice, such a task would have been too ambitious in light of the complexity of the transition process. In particular, it would have been necessary to model at the same time the factors affecting the equilibrium level of the BCPS ratio (that is, those factors determining the endpoint of the transition process) and the factors affecting the speed of the transition (such as

${ }^{8}$ For these countries, Table 3 focuses on developments in the last five years. 
Table 5. Bank Credit to the Private Sector: Annual Real Growth Rates, by Economic Sector, 1998-2001

\begin{tabular}{|c|c|c|c|c|c|c|}
\hline & 1998 & 1999 & 2000 & 2001 & 2002 & $\begin{array}{r}2000-20021 / \\
\text { (Cumulative) }\end{array}$ \\
\hline \multicolumn{7}{|l|}{ Albania } \\
\hline Credit to private sector & -10.9 & 11.3 & 29.8 & 24.1 & 23.6 & 99.0 \\
\hline Credit to enterprises & & & & 74.4 & 41.8 & 147.2 \\
\hline Credit to households & & & & -37.2 & -14.1 & -46.0 \\
\hline Real GDP & 7.9 & 7.3 & 7.8 & 6.5 & 4.7 & 20.2 \\
\hline \multicolumn{7}{|l|}{ Bosnia and Herzegovina } \\
\hline Credit to private sector & & 18.8 & 3.9 & 24.0 & 50.4 & 93.8 \\
\hline Credit to enterprises & & 13.4 & -0.4 & 13.6 & 28.8 & 45.6 \\
\hline Credit to households & & 43.3 & 17.6 & 52.9 & 93.7 & 248.0 \\
\hline Real GDP & 15.6 & 9.6 & 5.4 & 4.5 & 3.8 & 14.4 \\
\hline \multicolumn{7}{|l|}{ Bulgaria } \\
\hline Credit to private sector & 35.4 & 52.2 & 23.2 & 23.7 & 32.3 & 101.7 \\
\hline Credit to enterprises & 16.5 & 47.9 & 29.2 & 24.6 & 31.1 & 111.0 \\
\hline Credit to households & 764.6 & 71.4 & 4.8 & 20.7 & 37.1 & 73.5 \\
\hline Real GDP & 4.0 & 2.3 & 5.4 & 4.0 & 4.3 & 14.4 \\
\hline \multicolumn{7}{|l|}{ Croatia } \\
\hline Credit to private sector & 23.7 & 2.9 & -4.4 & 11.9 & 23.4 & 32.1 \\
\hline Credit to enterprises & 15.3 & -3.6 & -11.4 & 6.0 & 17.0 & 9.9 \\
\hline Credit to households & 51.3 & 18.1 & 9.5 & 21.6 & 32.1 & 75.9 \\
\hline Real GDP & 2.5 & -0.9 & 2.9 & 3.8 & 5.0 & 12.2 \\
\hline \multicolumn{7}{|l|}{ Czech Republic } \\
\hline Credit to private sector & -5.1 & -4.8 & -5.4 & -6.1 & -0.3 & -11.5 \\
\hline Credit to enterprises & -4.6 & -5.3 & -6.9 & -7.8 & -3.2 & -16.9 \\
\hline Credit to households & -9.5 & -0.8 & 6.7 & 6.5 & 17.2 & 33.3 \\
\hline Real GDP & -1.0 & 0.5 & 3.3 & 3.1 & 2.0 & 8.6 \\
\hline
\end{tabular}


Table 5 (continued). Bank Credit to the Private Sector: Annual Real Growth Rates, by Economic Sector, 1998-2001

\begin{tabular}{|c|c|c|c|c|c|c|}
\hline & 1998 & 1999 & 2000 & 2001 & 2002 & $\begin{array}{c}2000-20021 / \\
\text { (Cumulative) }\end{array}$ \\
\hline \multicolumn{7}{|l|}{ Estonia } \\
\hline Credit to private sector & 30.5 & 4.6 & 10.4 & 20.4 & 22.0 & 62.2 \\
\hline Credit to enterprises & 28.9 & 3.6 & 8.6 & 19.5 & 18.9 & 54.3 \\
\hline Credit to households & 39.0 & 8.6 & 18.9 & 23.9 & 34.0 & 97.4 \\
\hline Real GDP & 4.6 & -0.6 & 7.1 & 5.0 & 5.0 & 18.2 \\
\hline \multicolumn{7}{|l|}{ Hungary } \\
\hline Credit to private sector & 10.1 & 7.2 & 17.4 & 16.5 & 7.6 & 47.2 \\
\hline Credit to enterprises & 12.8 & 6.4 & 14.7 & 12.1 & -0.9 & 27.4 \\
\hline Credit to households & -6.0 & 13.1 & 36.7 & 43.3 & 45.9 & 185.7 \\
\hline Real GDP & 4.9 & 4.2 & 5.2 & 3.8 & 3.3 & 12.8 \\
\hline \multicolumn{7}{|l|}{ Latvia } \\
\hline Credit to private sector & 54.5 & 26.6 & 17.4 & 30.8 & 34.5 & 106.5 \\
\hline Credit to enterprises & 53.2 & 23.2 & 12.1 & 25.8 & 26.9 & 79.0 \\
\hline Credit to households & 65.6 & 52.5 & 50.6 & 55.3 & 61.7 & 278.1 \\
\hline Real GDP & 4.8 & 2.8 & 6.8 & 7.9 & 6.1 & 22.4 \\
\hline \multicolumn{7}{|l|}{ Lithuania } \\
\hline Credit to private sector & 4.5 & 12.7 & -4.7 & 26.1 & 29.6 & 55.8 \\
\hline Credit to enterprises & 3.7 & 10.6 & -3.0 & 26.2 & 23.7 & 51.5 \\
\hline Credit to households & 37.1 & 27.0 & -14.6 & 24.9 & 69.6 & 80.8 \\
\hline Real GDP & 7.3 & -1.8 & 4.0 & 6.5 & 5.6 & 17.0 \\
\hline \multicolumn{7}{|l|}{ Macedonia } \\
\hline Credit to private sector & -15.3 & -9.8 & 2.1 & -7.8 & -1.8 & -7.5 \\
\hline Credit to enterprises & -16.6 & -10.3 & 0.8 & -9.6 & -4.3 & -12.8 \\
\hline Credit to households & 13.1 & -0.3 & 18.7 & 16.9 & 20.6 & 67.4 \\
\hline Real GDP & 3.4 & 4.3 & 4.5 & -4.1 & 0.1 & 0.3 \\
\hline
\end{tabular}


Table 5 (concluded). Bank Credit to the Private Sector: Annual Real Growth Rates, by Economic Sector, 1998-2001

\begin{tabular}{|c|c|c|c|c|c|c|}
\hline & 1998 & 1999 & 2000 & 2001 & 2002 & $\begin{array}{r}2000-20021 / \\
\text { (Cumulative) }\end{array}$ \\
\hline \multicolumn{7}{|l|}{ Poland } \\
\hline Credit to private sector & 15.6 & 17.8 & 12.9 & 7.4 & 4.1 & 26.3 \\
\hline Credit to enterprises & 14.8 & 16.9 & 9.4 & 3.7 & 0.6 & 14.1 \\
\hline Credit to households & 21.1 & 22.9 & 23.3 & 15.3 & 9.7 & 56.0 \\
\hline Real GDP & 4.8 & 4.1 & 4.0 & 1.0 & 1.3 & 6.5 \\
\hline \multicolumn{7}{|l|}{ Romania } \\
\hline Credit to private sector & 20.0 & -2.0 & -19.3 & 5.4 & 26.0 & 7.2 \\
\hline Credit to enterprises & 19.6 & -1.3 & -19.0 & 4.8 & 23.1 & 4.5 \\
\hline Credit to households & 26.0 & -12.7 & -23.9 & 16.2 & 68.2 & 48.7 \\
\hline Real GDP & -4.8 & -1.2 & 2.1 & 5.7 & 4.9 & 13.2 \\
\hline \multicolumn{7}{|l|}{ Serbia 2/ } \\
\hline Credit to private sector & & & 0.1 & -67.7 & 23.1 & -60.2 \\
\hline Credit to enterprises & & & 0.7 & -68.8 & 15.2 & -63.8 \\
\hline Credit to households & & & -24.7 & 8.1 & 189.2 & 135.5 \\
\hline Real GDP & 2.5 & -18.0 & 5.0 & 5.5 & 4.0 & 15.2 \\
\hline \multicolumn{7}{|l|}{ Slovak Republic } \\
\hline Credit to private sector & -1.2 & -1.2 & -3.8 & -14.0 & -12.3 & -27.5 \\
\hline Credit to enterprises & -2.2 & -2.9 & -5.8 & -17.2 & -16.0 & -34.5 \\
\hline Credit to households & 16.0 & 24.6 & 20.8 & 14.1 & 13.8 & 56.9 \\
\hline Real GDP & 4.0 & 1.3 & 2.2 & 3.3 & 4.4 & 10.2 \\
\hline \multicolumn{7}{|l|}{ Slovenia } \\
\hline Credit to private sector & 12.0 & 19.0 & 15.1 & 7.7 & 5.6 & 30.9 \\
\hline Credit to enterprises & 12.0 & 15.7 & 12.6 & 11.1 & 8.3 & 35.5 \\
\hline Credit to households & 12.1 & 26.6 & 20.9 & 0.5 & -0.5 & 21.0 \\
\hline Real GDP & 3.8 & 5.2 & 4.6 & 3.0 & 2.9 & 10.8 \\
\hline
\end{tabular}

Source: Appendix I.

${ }^{1}$ 2001-02 for Albania.

${ }^{2}$ For 2001 and 2002, end-of-period data are used. 
Figure 2. Change in Credit-to-GDP Ratio, by Sector, 1997-2002

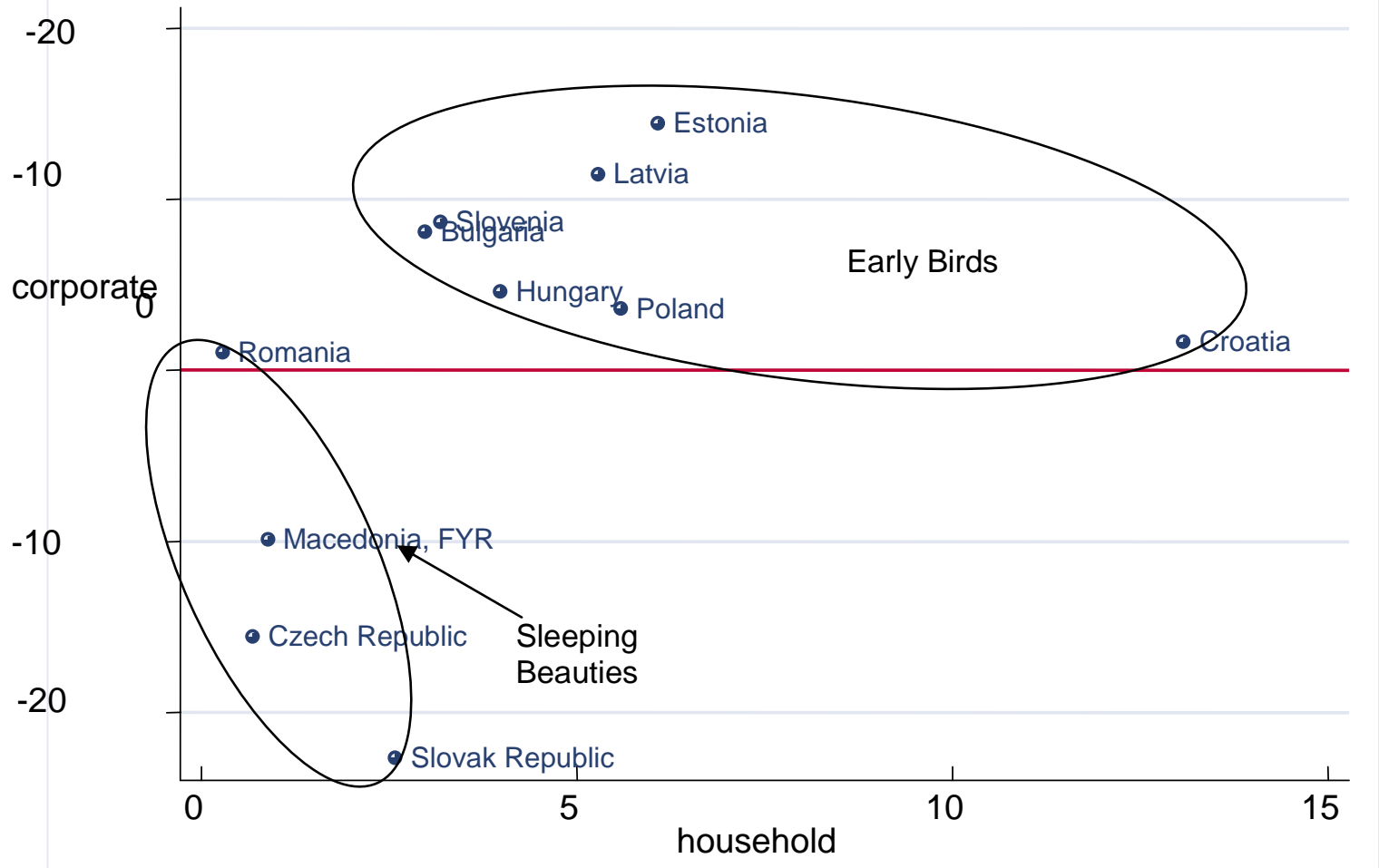

Source: Appendix I. 
the process of gradual introduction of market economy features in the financial system) plus ordinary adjustment lags. Such a model, particularly its dynamic specification, would have been difficult to estimate because of the short time dimension of the country panel. ${ }^{9}$

We regarded this approach as too ambitious and proceeded in the following way. First we discuss informally, on the basis of available statistics, the factors that are likely to explain the observed behavior of the BCPS ratio across CEB countries. Second, we assess how these factors, as well as any other relevant factors, are likely to evolve in the future. Finally, we try to assess by how much the BCPS ratio in these countries differs from its long-term equilibrium by estimating, for a sample of non transition countries, the factors affecting the equilibrium level of the BCPS ratio, and by using this model to make projections for CEB countries.

\section{A. Lessons From the Past}

If we look at how BCPS ratios evolved across countries in relation to changes in other relevant structural and macroeconomic variables, the following facts stand out:

- $\quad$ There is no clear evidence that the different credit growth performance reflected primarily initial conditions in the level of bank intermediation, i.e., that faster growth was primarily the result of catching-up. In the early birds, the average BCPS ratio before the turning-point year (the year when the BCPS ratio started rising) was indeed quite low (14.2 percent; Table 6, first column), half of what it was in the sleeping beauties during the late 1990s. This would suggest that the early birds rose more because they started from a low bank intermediation level. However, the ratio in the early birds has continued to increase well above the level of the sleeping beauties, averaging 29 percent in 2001 and 32.6 percent in 2002 .

- There is also no evidence that the process was driven by the capability of the banking system of the early birds to attract financing from abroad. The average annual increase in net foreign liabilities (in percent of GDP) was almost zero in the early birds, while it was 0.6 percentage points of GDP in the sleeping beauties (Tables 3 and 4). Indeed, in some of the early birds the net external position of banks even improved markedly (Bulgaria, Croatia, Hungary) during the period when the BCPS ratio was rising. ${ }^{10}$

${ }^{9}$ OLS estimates of dynamic models including a lagged dependent variable are biased (and consistency properties do not apply if the time dimension is short). While instrumental variables can be use to correct for the bias (as in the GMM Arellano-Bond estimator), the quality of the results are only commensurate to the quality of the instruments. In addition, by using lagged values of the variables as instruments, GMM techniques further reduce the time-series dimension of the panel.

${ }^{10}$ The net foreign assets of Serbian banks would have also increased in 2002, the turning point year, (or, alternatively, credit growth would have been higher) were it not for the fact 
Table 6. Factors Affecting Bank Credit Growth: Does Initial Size Matter? Does Fiscal Policy Matter?

\begin{tabular}{lcccc}
\hline & $\begin{array}{c}\text { BCPS Ratio Before } \\
\text { Turning Point }\end{array}$ & $\begin{array}{c}\text { BCPS Ratio } \\
\text { in 2001 }\end{array}$ & $\begin{array}{c}\text { BCPS Ratio } \\
\text { in 2002 }\end{array}$ & $\begin{array}{c}\text { Average Fiscal } \\
\text { Deficit }^{2}\end{array}$ \\
\hline Early birds & & & & \\
Bulgaria & 4.6 & 12.3 & 15.6 & 0.5 \\
Croatia & 24.8 & 38.8 & 45.6 & 3.2 \\
Estonia & 10.7 & 39.6 & 46.0 & 0.4 \\
Hungary & 20.1 & 28.1 & 29.3 & 5.0 \\
Latvia & 6.9 & 19.6 & 24.8 & 2.1 \\
Poland & 15.2 & 27.4 & 28.1 & 3.5 \\
Slovenia & 16.8 & 37.4 & 38.4 & 0.7 \\
Average & 14.2 & 29.0 & 32.6 & 2.2 \\
& & & & \\
Late risers & & & & 4.3 \\
Bosnia and Herzegovina & 12.7 & 15.1 & 21.9 & 5.0 \\
Serbia and Montenegro ${ }^{2}$ & - & 12.4 & 14.7 & 1.2 \\
Lithuania & 11.6 & 11.6 & 14.2 & 3.5 \\
Average & -- & 13.0 & 16.9 & \\
& & & & \\
Sleeping beauties & & 4.2 & 4.9 & 3.2 \\
Albania & 3.3 & 43.5 & 42.6 & 2.3 \\
Czech Republic & 53.3 & 17.4 & 17.1 & 3.7 \\
Macedonia, FYR & 21.7 & 6.9 & 8.3 & 4.4 \\
Romania & 6.7 & 37.5 & 31.5 & \\
Slovak Republic & 48.5 & 21.9 & 20.9 & \\
Average & 26.7 & & & \\
& & & & \\
\hline
\end{tabular}

Source: Appendix I.

${ }^{1}$ 1996-2000 average for the sleeping beauties, except Slovak Republic (1997-2000).

${ }^{2}$ In percent of GDP; general government, cash basis. The deficit is averaged over the reference period as defined in Table 3.

${ }^{3}$ Consistent figures for 2000 (the year before the turning point) are not available as available data include the four state banks loans closed in early 2002.

- The growth in the BCPS ratio was essentially driven by domestic saving flows (although in some countries, notably Estonia and Latvia, external borrowing was also sizable). Indeed, the annual increase in the BCPS ratio in the early birds is broadly in line with the

that the central bank imposed a 50 percent liquidity requirement to slow down deposit and credit expansion. 
increase in the bank deposit-to-GDP ratio, a reflection of increased overall financial deepening. However, the deposit-to-GDP ratio did increase also in the sleeping beauties (although not as fast), but there was no corresponding rise in the BCPS ratio. Thus, overall financial deepening was not a sufficient condition for increasing BCPS ratios.

- Crowding-in may have been a factor. In all but one of the early birds (Latvia) bank credit to the public sector ratio declined, while on average it increased for the sleeping beauties (Table 4). ${ }^{11}$ The role of crowding-in is confirmed by the fact that the average general government deficit-to-GDP ratio in the early birds during the period of rising BCPS ratio (21/4 percent of GDP; Table 6$)$ was half of what it was in the sleeping beauties during the last five years $\left(4 \frac{1}{2}\right.$ percent $)$.

- One factor that may help explain differences across countries is the degree of progress on structural reforms. It stands to reason that BCPS is unlikely to grow very fast in countries still at an early stage of transition, i.e., where the private sector has not developed much. Indeed, the average EBRD "transition index" of early birds is higher than the average for the sleeping beauties (Table 7). ${ }^{12}$ The effect of the overall transition process is, however, not entirely clear. Two of the sleeping beauties (Czech Republic and Slovak Republic) rank high in the transition ladder. Similar conclusions are reached by looking at the EBRD transition index describing the degree of banking reform and interest rate liberalization, although the differences between early birds and sleeping beauties are here more significant ${ }^{13}$ (Table 7).

- A specific aspect of the transition process that seems to have been more important is the degree of private sector ownership of banks. Banks were privatized earlier in the early birds. Already at the end of the 1990s the asset share of state-owned banks had dropped to 25 percent in the average of the early birds (only to fall to below 16 percent by end2001; Table 8). On the contrary, the asset share of public banks was over 41 percent in the sleeping beauties in 1999. ${ }^{14}$ Moreover, the surge in bank credit in the late risers in 2002 was preceded by key privatization operations (which lowered the share of public

${ }^{11}$ The average figure for the sleeping beauties underestimates somewhat the increase in credit to the government, as it includes Albania where the decline in credit to the government was matched by a decline in government deposits in banks, with no change in net credit.

${ }^{12}$ As indicated in Table 7, the transition index for each country is computed as the simple average of the various EBRD transition indexes (see Table 2.1 in EBRD (2002)).

${ }^{13}$ For the overall transition index, the average for early birds is not significantly different from the average for sleeping beauties at standard significance levels. Instead, for the transition index for banking reform and interest rate liberalization the average for early birds is signficant from the average for sleeping beauties at 10 percent in a one-tailed test.

14 The difference in private ownership shares between sleeping beauties and early birds is significant at a 10 percent level in one- and two-tailed tests in 2000 , but neither test is passed for 2001 . 
Table 7. Factors Affecting Bank Credit Growth: The Role of the Transition Process (EBRD Index, 1989-2002 averages)

\begin{tabular}{lccc}
\hline All & indexes ${ }^{1}$ Bank & $\begin{array}{c}\text { ing Sector and } \\
\text { Interest Rate } \\
\text { Liberalization }\end{array}$ & $\begin{array}{c}\text { Legal Transition } \\
\text { Indicators (Commercial } \\
\text { Law) }\end{array}$ \\
\hline Early birds & & & \\
Bulgaria & & & \\
Croatia & 2.25 & 2.14 & 3.73 \\
Estonia & 2.49 & 2.33 & 3.35 \\
Hungary & 2.67 & 2.74 & 3.53 \\
Latvia & 3.03 & 3.00 & 3.73 \\
Poland & 2.43 & 2.68 & 3.20 \\
Slovenia & 2.98 & 2.76 & 3.55 \\
Average & 2.68 & 2.59 & 3.53 \\
& 2.65 & 2.61 & 3.52 \\
Late risers & & & \\
Bosnia and Herzegovina & 1.61 & 1.48 & -- \\
Serbia and Montenegro & 1.54 & 1.10 & 3.46 \\
Lithuania & 2.44 & 2.29 & -- \\
Average & 1.86 & 1.62 & \\
& & & 2.33 \\
Sleeping Beauties & & & 3.40 \\
Albania & 2.02 & 2.74 & 3.46 \\
Czech Republic & 2.85 & 2.24 & 3.73 \\
Macedonia, FYR & 2.27 & 2.05 & 3.20 \\
Romania & 2.16 & 2.50 & \\
Slovak Republic & 2.68 & & \\
Average & 2.40 & & \\
& & & \\
\hline
\end{tabular}

Source: Appendix I.

${ }^{1}$ Simple averages of the nine transition indexes published in the EBRD transition reports. The transition indexes range from 1 (less advanced) to $4+$ (more advance). In calculating the averages, $\mathrm{X}+$ is set equal to $\mathrm{X}+0.33$ while $\mathrm{X}-$ is set at $\mathrm{X}-0.33$. 
banks in $\mathrm{BiH}$ and Lithuania to close to 10 percent at end-2001). ${ }^{15}$ It should be added that the available data do not allow us to understand whether it is privatization per se or foreign ownership that matters. Privatization has consisted primarily of sales to foreigners, with the share of foreign ownership of banks currently exceeding 80 percent in a number of countries (Table 8).

- Credit growth is likely to be affected by the degree to which legislation protects creditors' rights. The EBRD publishes a legal transition index focusing on the extensiveness of legislation on bankruptcy, company, and pledge laws, as well as on its effective implementation. The last column of Table 7 reports the averages of this index during 1998-02, and shows that early birds have a stronger legislation in this area. Indeed, only one sleeping beauty (Romania) has an index that exceeds the average index for early birds. Conversely, only one early bird (Latvia) has an index that does not exceed the average for the sleeping beauties. The differences in the average index for the two country groups is, however, small, and indeed, non-significant at the 10 percent level.

In sum, data suggest that - in the context of increased overall financial deepeningprivatization, public sector retrenchment, and, possibly, the overall progress towards market institutions and the quality of legislation to protect creditors' rights have been key factors behind rising BCPS ratios. ${ }^{16}$

\section{B. The Outlook for BCPS Growth: Microeconomic Factors}

Microeconomic forces relating to the behavior of both banks and borrowers are likely to lead to strong credit growth across the CEB areas in the years ahead, as factors that are likely to have constrained this growth in recent years are being removed. In this respect, three considerations are important. They relate to bank ownership, bank profitability, and credit risk.

15 The lag between privatization and BCPS growth is, however, variable. In Hungary, for example, the BCPS ratio started rising only a couple of years following the major privation operations of 1995-96. Conversely, key privatization operations that brought the market share of state banks in Slovakia and in the Czech Republic during 2001 have not yet resulted in a rise in the BCPS ratio.

${ }^{16}$ Other factors may also have been at play. Feldman and Wagner (2002) and Watson (2003), for example, point at the role of FDI. Strong FDI, and related credit from parent companies (or from foreign banks providing credit to parent companies), may be a substitute for bank credit growth. This may explain, at least in part, relatively slow bank credit growth in the Czech Republic and in Slovakia, and, among the early birds, in Hungary (where intercompany loans exceeded 9 percent of GDP at the end of 2002). Regarding the Czech Republic and Slovakia, the prolonged process of cleaning up of the banks' portfolio may also have contributed to delaying the growth of the bank loan market. It should also be recalled that the Czech data include credit to state enterprises (Appendix I), which may have declined. 
Table 8. Factors Affecting Bank Credit Growth: Privatization and Foreign Ownership

\begin{tabular}{|c|c|c|c|c|c|}
\hline \multirow[b]{3}{*}{ Early birds } & \multicolumn{3}{|c|}{ Asset Share of State-Owned Banks } & \multicolumn{2}{|c|}{$\begin{array}{c}\text { Asset of Banks Controlled by } \\
\text { Nonresidents }^{2}\end{array}$} \\
\hline & \multicolumn{2}{|l|}{19992000} & \multirow[t]{2}{*}{2001} & & \\
\hline & & & & & \\
\hline Bulgaria & 50.5 & 19.8 & 19.9 & 74.0 & (2001) \\
\hline Croatia & 39.8 & 5.7 & 5.0 & 84.0 & (2001) \\
\hline Estonia & 7.9 & 0.0 & 0.0 & 82.0 & (2000) \\
\hline Hungary & 7.8 & 7.7 & 9.0 & 84.9 & (2001) \\
\hline Latvia & 2.6 & 2.9 & 3.2 & 70.0 & $(2000)^{3}$ \\
\hline Poland & 23.9 & 22.9 & 23.1 & 69.2 & $(2001)$ \\
\hline Slovenia & 41.7 & 42.2 & 48.4 & 18.4 & $(2001)$ \\
\hline Average & 25.0 & 14.6 & 15.7 & -- & \\
\hline \multicolumn{6}{|l|}{ Late risers } \\
\hline Bosnia and Herzegovina & 75.9 & 55.4 & 8.9 & 66.3 & $(2002)^{3}$ \\
\hline Serbia and Montenegro & 89.0 & 90.9 & 68.0 & 15.1 & $(2002)$ \\
\hline Lithuania & 41.9 & 38.9 & 12.2 & n.a. & \\
\hline Average & 68.9 & 61.7 & 29.7 & -- & \\
\hline \multicolumn{6}{|l|}{ Sleeping beauties } \\
\hline Albania & 81.1 & 64.8 & 59.2 & 44.7 & (2002) \\
\hline Czech Republic & 23.1 & 28.2 & 3.8 & 84.0 & (2001) \\
\hline Macedonia, FYR & 1.3 & 1.1 & 1.3 & 44.0 & $(2002)$ \\
\hline Romania & 50.3 & 50.0 & 45.4 & n.a. & \\
\hline Slovak Republic & 50.7 & 49.1 & 4.9 & 88.6 & (2001) \\
\hline Average & 41.3 & 38.6 & 22.9 & -- & \\
\hline
\end{tabular}

Source: Appendix I.

${ }^{1}$ Data are from EBRD (2002).

${ }^{2}$ Data refer to the year indicated in parenthesis. Control is defined as ownership of at lest 50 percent of capital.

${ }^{3}$ Share of bank capital owned by nonresidents.

Ownership. As discussed above, privatization seems to have been critical in explaining rapid credit growth in the early birds. Looking ahead, the virtual completion of bank privatization in two of the sleeping beauties (Czech Republic and Slovakia) in 2001, taking account of the length of lags observed in other countries (one-two years), should result in an acceleration of credit growth in the near future. The governments of Albania and Romania have also attempted key privatization operations in 2002. They failed due to poor market conditions, but the intention to privatize remains. Weak market conditions also hindered the privatization of NKBM in Slovenia, which, however, succeeded to sell one third of another large state bank (NLB). Privatization is continuing also in the early birds. For example, the Bulgarian government recently privatized DSK, the last large government-owned bank. In sum, the ongoing further privatization of banks is likely to provide new impetus to credit growth. 
Profitability. Bank profitability is low in CEB countries compared with the EU. Bankscope data indicate that, excluding Albania ${ }^{17}$, in 2001 the return on equity (ROE), adjusted for inflation, was below the EU average in all CEB countries except Estonia and Latvia (Table 9), despite the fact that 2001 was not a particularly good year for EU banks. As argued by Riess, Wagenvoort and Zajc (2002), this lower profitability is due, at least in part, to the relatively low level of bank loans over total assets. CEB banks have invested a sizable amount of resources in fairly liquid assets - like deposits abroad and, particularly in countries where sterilized intervention operations by the central bank have been large (Czech Republic, Slovak Republic ${ }^{18}$ ), central bank liabilities. Looking ahead, once risk conditions on the loan market improve, CEB banks are likely to try to boost their profitability by expanding bank loans.

Credit risk. Risk conditions critically reflect regulations and practices affecting creditors' rights. Weaker legislation in this area was identified above as a feature of the sleeping beauties. Moreover, the inadequacy of these regulations and practices (including the inefficient working of courts involved in legal decision regarding the recovery of credit) is quoted among the key factors preventing credit growth in most Financial Systems Stability Assessments (FSSAs) prepared during the last three years for CEB countries by IMF and World bank staff (Table 10). CEB countries are continuing to make progress in this area. As to the actual availability of collateral, the integration of CEB countries with Western Europe is likely to lead to a convergence in real estate prices, and, hence, in the value of a key form of available collateral.

How much scope is there for BCPS ratios to rise further as a result of these microeconomic forces and, more generally, of the "convergence towards Europe" as the transition process is completed? As noted by others, the BCPS ratio in CEB countries is currently well below that of other European countries (Table 11). It should be noted that BCPS ratios appear undersized also after controlling for differences in the overall degree of development, as proxied by per-capita GDP. Indeed, the current level of the BCPS ratio in CEB countries is well below not only that of euro-area countries, but also that of countries with similar per capita income (Figure 3).

${ }^{17}$ The high ROER in Albania is explained by market imperfections. The bulk of the liabilities of Albanian banks (in particular the public Savings Bank) is represented by deposits that receive an interest well below that of treasury bills (the main assets in the hands of banks), given the impediments for Albanian savers to invest directly on the treasury bill market. The very negative ROER in the Czech Republic refers to a year when the restructuring of the Czech banking system related to the late privatization was still in progress

${ }^{18}$ See footnotes 7 and 9 in Table 3. 
Table 9. Bank Profitability in CEB Countries, 2001

\begin{tabular}{lcrrr}
\hline & No. of Banks ${ }^{1} \mathrm{RO}$ & $\mathrm{A}^{2} \mathrm{ROE}$ & ${ }^{3} \mathrm{ROE}$ & $\mathrm{R}^{4}$ \\
\hline Early birds & & & & \\
$\quad$ Bulgaria & 28 & 1.78 & 13.31 & 5.40 \\
Croatia & 42 & 0.98 & 9.18 & 2.81 \\
Estonia & 11 & 2.70 & 20.50 & 13.94 \\
Hungary & 44 & 1.09 & 16.40 & 6.59 \\
Latvia & 26 & 1.85 & 21.52 & 18.58 \\
Poland & 42 & 1.01 & 8.59 & 2.93 \\
Slovenia & 23 & 0.85 & 8.35 & -0.08 \\
& & & & \\
Average & ---- & 1.47 & 13.98 & 7.17 \\
& & & & \\
Late risers & & & & \\
Bosnia and Herzegovina & 19 & 0.19 & 2.05 & -1.05 \\
Serbia and Montenegro & 16 & 0.10 & 2.18 & -46.53 \\
Lithuania & 16 & 0.83 & 7.94 & 6.51 \\
& & & & \\
Sleeping beauties & & & & \\
Albania & 5 & 2.99 & 49.42 & 44.90 \\
Czech Republic & 33 & -3.66 & -60.84 & -62.60 \\
Macedonia, FYR & 11 & 0.10 & 0.62 & -4.44 \\
Romania & 30 & 1.58 & 10.32 & -17.98 \\
Slovak Republic & 22 & 0.95 & 15.39 & 7.54 \\
Average & & & & -4.96 \\
EU average & ---- & 0.88 & & \\
4439 & & & & \\
\hline
\end{tabular}

Source: Calculations on Bankscope data.

${ }^{1}$ Number of banks included in the Bankscope sample.

${ }^{2}$ The ROA is defined as net income in percent of total average assets.

${ }^{3}$ The ROE is defined as net income in percent of total average equity.

${ }^{4}$ Real ROE defined as $\{[(1+\mathrm{ROE}) /(1+\mathrm{P})]-1\} * 100$ where $\mathrm{P}$ is the average CPI inflation rate.

${ }^{5}$ Excluding Albania and Czech Republic. 
Table 10. Subjective Assessment of Factors Preventing Faster Bank Credit Growth to the Private Sector ${ }^{1}$

Weak creditor right ${ }^{2} 87.5$

Dearth of trustworthy borrowers

50.0

Need to complete to the bank restructuring process

50.0

after crisis or change in ownership

Poor accounting standards

37.5

Direct financing from abroad

25.0

Other $^{3} 37.5$

Source: Appendix I.

${ }^{1}$ Based on the views expressed in the Financial Sector Stability Assessments prepared for Bulgaria, Croatia, Czech Republic, Estonia, Hungary, Lithuania, Poland, and Slovak Republic.

${ }^{2}$ Reflecting one or more of the following: inadequate insolvency law, slow working of courts, lack of experience of trustees, and inadequate regulations on the recovery of collateral.

${ }^{3}$ Crowding out, limited credit information databases, and inadequate legislation on corporate governance. 
Table 11. Per Capita Income and BCPS Ratios in the Euro Area and in CEB Countries

\begin{tabular}{|c|c|c|}
\hline $\mathrm{Pe}$ & $\begin{array}{l}\text { r Capita Income }^{1} \\
(2001)\end{array}$ & $\begin{array}{c}\text { BCPS Ratio } \\
(2001)\end{array}$ \\
\hline \multicolumn{3}{|l|}{ Euro Area } \\
\hline Austria & 26,919 & 103.1 \\
\hline Belgium & 28,060 & 77.4 \\
\hline Finland & 26,539 & 54.4 \\
\hline France & 24,828 & 86.7 \\
\hline Germany & 25,653 & 119.3 \\
\hline Greece & 16,695 & 55.8 \\
\hline Ireland & 30,305 & 101.7 \\
\hline Italy & 25,119 & 76.5 \\
\hline Netherlands & 26,331 & 135.8 \\
\hline Portugal & 17,088 & 137.8 \\
\hline Spain & 21,179 & 99.9 \\
\hline Average & 24,428 & 95.3 \\
\hline \multicolumn{3}{|l|}{ CEB Countries } \\
\hline Albania & 3,750 & 4.2 \\
\hline Bosnia and Herzegovina & 3,869 & 29.9 \\
\hline Bulgaria & 5,947 & 12.3 \\
\hline Croatia & 8,304 & 38.8 \\
\hline Czech Republic & 15,146 & 43.5 \\
\hline Estonia & 9,555 & 25.0 \\
\hline Hungary & 13,030 & 29.1 \\
\hline Latvia & 7,547 & 19.6 \\
\hline Lithuania & 7,521 & 11.6 \\
\hline Macedonia, FYR & 4,851 & 17.4 \\
\hline Poland & 9,790 & 27.4 \\
\hline Romania & 6,927 & 6.9 \\
\hline Serbia and Montenegro & 5,826 & 12.4 \\
\hline Slovak Republic & 11,252 & 29.4 \\
\hline Slovenia & 17,819 & 37.4 \\
\hline Average & 8,742 & 22.9 \\
\hline
\end{tabular}

Source: Appendix I.

${ }^{1}$ In U.S. dollars at purchasing power parity. 
Figure 3. Bank Credit to Private Sector-to-GDP Ratio and Purchasing Power Parity (PPP) Per Capita Income, 2001

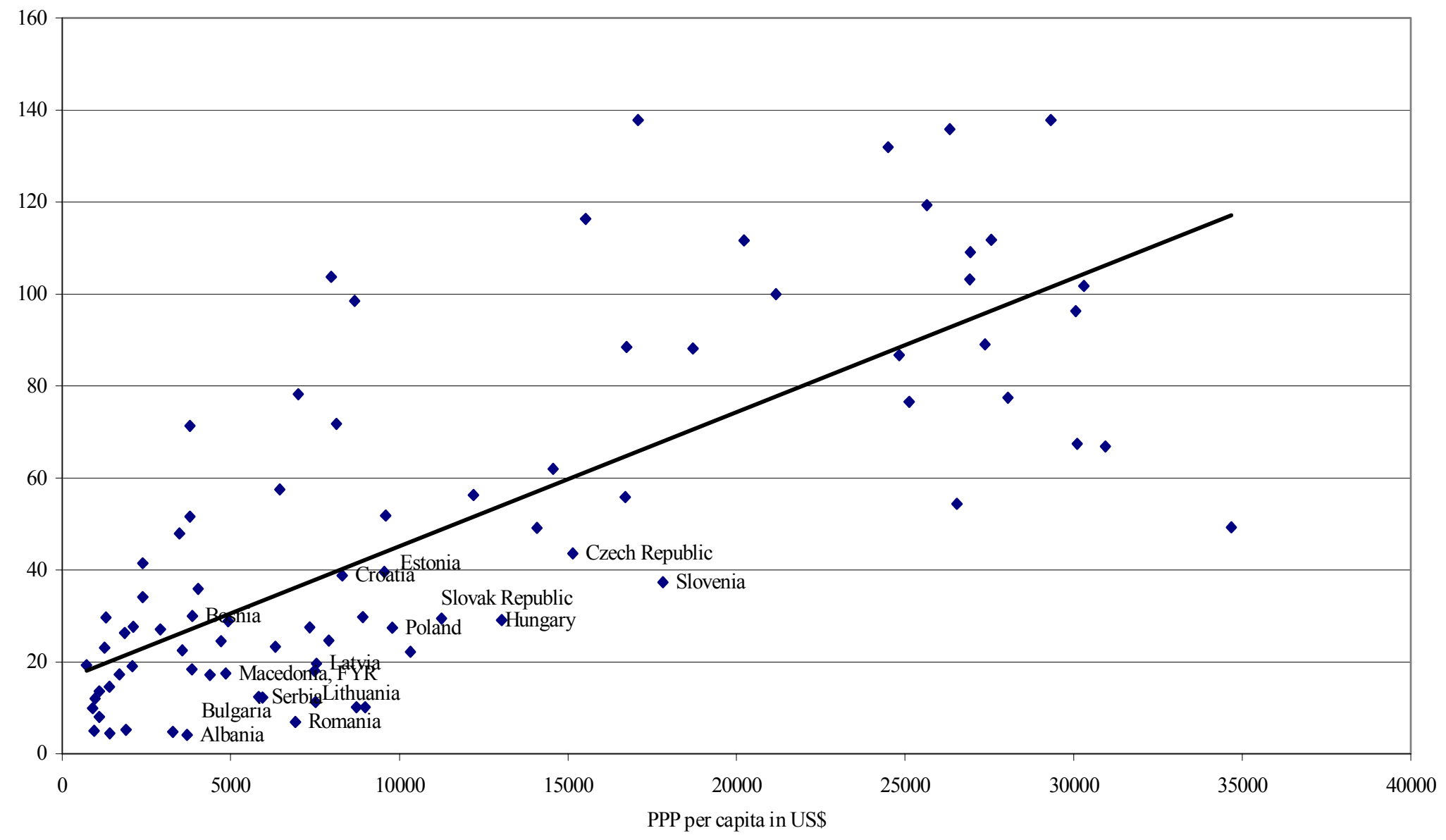

Sources: IMF, World Economic Outlook, and International Financial Statistics; and IMF staff estimates. 
A more formal analysis of the scope for further growth in the BCPS ratio in CEB countries can be based on an assessment of the factors affecting long term trends in BCPS ratios. For this purpose we estimated an econometric model of the BCPS ratio based on a panel of nontransition developing and industrialized countries. ${ }^{19}$

The model-summarized in Table 12 (see Appendix II for details on its specification and estimation) - draws from previous empirical models of the BCPS ratio, but is more comprehensive, controls explicitly for breaks in the bank credit series, and has a better overall fit. It relates the BCPS ratio to:

- The public debt-to-GDP ratio as an indicator of the level of crowding out.

- Per capita GDP as an indicator of overall economic development of a country. ${ }^{20}$

- Inflation, through a threshold effects whereby the latter is expected to have a negative but nonlinear effect on the BCPS ratio.

- Indexes of financial liberalization, bank entry requirements and quality of accounting standards.

- The legal origin of the country, where it is found that countries with German legal origin have a higher BCPS ratio, as in Levine, Loayza, and Beck (2000). ${ }^{21}$

- A trend, introduced for controlling for any omitted trend variable, whose coefficient is, however, fairly small.

The estimated coefficients were then used to evaluate the equilibrium level of the BCPS ratio for CEB countries. The results are reported in panel B of Table 12. They show that BCPS ratios in almost all CEB countries are still significantly undersized. While the degree of

${ }^{19}$ The model, rather than trying to assess causality, attempts to identify the long-term relationship between BCPS ratio and a set of variables. Some of the latter, in particular percapita GDP, may be endogenous, as there is a consistent body of literature arguing that the degree of financial deepening has effects on growth. However, this endogeneity problem is not critical if one is not interested in assessing the line of causality, but simply the level of credit ratio towards which countries will tend to converge.

${ }^{20}$ Another possible interpretation of the link between BCPS ratio and percapita GDP is the following. Assuming that the optimal leverage ratio is not affected by the level of capital stock, and that the ratio between capital stock and output rises with the level of per capita income (i.e., high-income countries have a larger per capita capital endowment), it follows that BCPS ratios should be positively correlated to percapita output.

${ }^{21}$ Many European countries are characterized as having a German legal origin. This dummy may simply capture the fact that financial systems in continental Europe have been, for historical reasons, bank-centered. CEB countries seem to have adopted the same financial development model (see Table 1). Thus, for the purpose of estimating their BCPS ratio equilibrium level they are classified as having German origin. 
Table 12. Econometric Model of Determinants of the BCPS Ratio

A. Random Effects Panel Regression, Nontransition Countries, 1973-6

\begin{tabular}{|c|c|c|c|c|}
\hline & Coefficient & Standard Error & t-statistic & \\
\hline Public Debt / GDP & -0.136 & 0.032 & -4.29 & *** \\
\hline Log (GDP per capita) & 0.084 & 0.022 & 3.74 & $* * *$ \\
\hline (1- High-inflation dummy) $^{*}(1 /$ Inflation rate - 1/Inflation threshold) & 0.000 & 0.000 & 1.08 & \\
\hline High-inflation dummy*(1/Inflation rate - 1/Inflation threshold) & 0.004 & 0.001 & 4.66 & *** \\
\hline Liberalization index & 0.190 & 0.034 & 5.64 & *** \\
\hline Bank entry requirements & -0.024 & 0.022 & -1.1 & \\
\hline Accounting 0 & .007 & 0.003 & 2.74 & $* * *$ \\
\hline German legal origin & 0.287 & 0.086 & 3.34 & *** \\
\hline Trend & 0.002 & 0.002 & 1.28 & \\
\hline Constant & -0.665 & 0.249 & -2.68 & *** \\
\hline Number of observations & 468 & & & \\
\hline R-squared & 0.66 & & & \\
\hline \multicolumn{5}{|l|}{ B. Out-of-Sample Predicted Values for BCPS Ratio, CEB Countries } \\
\hline & $\begin{array}{c}\text { Actual } \\
\text { BCPS ratio, } \\
2002\end{array}$ & Predicted Value & $\begin{array}{l}\text { Absolute } \\
\text { Deviation }\end{array}$ & \\
\hline & $a$ & $\bar{b}$ & $a-b$ & \\
\hline Albania & 4.9 & 24.6 & -19.7 & \\
\hline Bosnia & 21.9 & 18.5 & 3.5 & \\
\hline Bulgaria & 15.6 & 52.6 & -37.0 & \\
\hline Croatia & 45.6 & 49.1 & -3.5 & \\
\hline Czech Republic & 42.6 & 69.3 & -26.7 & \\
\hline Estonia & 46.0 & 75.4 & -29.4 & \\
\hline Hungary & 29.3 & 70.5 & -41.2 & \\
\hline Latvia & 24.8 & 76.7 & -51.9 & \\
\hline Lithuania & 14.2 & 68.1 & -53.9 & \\
\hline Macedonia, FYR & 17.1 & 44.2 & -27.1 & \\
\hline Poland & 28.1 & 70.4 & -42.3 & \\
\hline Romania & 8.3 & 58.0 & -49.7 & \\
\hline Serbia & 14.7 & 21.0 & -6.3 & \\
\hline Slovak Republic & 31.5 & 59.9 & -28.4 & \\
\hline Slovenia & 38.4 & 63.8 & -25.4 & \\
\hline
\end{tabular}

Source: Appendix I.

Notes: $*, * *, * * *$ denote significance at 10 percent, 5 percent and 1 percent significance levels, respectively The regression includes dummy variables controlling for breaks in the BCPS ratio data (see Appendix) The inflation threshold is 4 percent. 
underdevelopment varies across countries, it is remarkable that the average deviation from equilibrium is fairly similar in the sub-groups of sleeping beauties and early birds (about 3330 percentage points of GDP). The BCPS ratio seems to be close to equilibrium only in Croatia and SM (although in the latter the data include also public enterprises). It is somewhat above equilibrium only in Bosnia, following the strongest increase (equaled only by Croatia) in the BCPS ratio in the region in 2002 (63/4 percentage points).

It should finally be noted that, over time, the equilibrium levels are expected to rise reflecting expected developments in the explanatory variables.

\section{The Outlook for BCPS Growth: Macroeconomic Factors}

Two main macroeconomic forces are likely to lead to rapid growth of BCPS.

Crowding-in. In most countries experiencing a rising BCPS ratio, the rise has been accompanied by a falling bank credit to the government ratio. This process of crowding in is likely to continue under the constraints set by the euro-convergence process. In this respect, there is still some way to go: Table 13 shows the 2002 fiscal deficit-to-GDP level in CEB countries, together with each government's stated medium-term objective. On average, the fiscal deficit ratio is targeted to decline by $1 \frac{1}{4}$ percentage point of GDP during 2003-05.

Capital inflows. Banks can expand their available resources not only through domestic deposits, but also by attracting net credit from abroad. ${ }^{22}$ Net credit from abroad is likely to increase for two reasons. First, commercial banks in two thirds of the CEB countries were, in the average of 2002 net lenders to the rest of the world. Only in five countries (BiH, Czech Republic, Estonia, Latvia, and Poland) banks were net borrowers, and in only two of these countries (Czech Republic and Poland) the net exposure of banks exceeded 10 percent of GDP. This net asset position, or limited exposure, should in the future facilitate access to external credit. This access should also be facilitated by the fact that CEB banks are largely owned by banks of existing euro-area members. Second, and more generally, the process of euro-convergence is likely to involve strong capital inflows into the region, in the context of large differences in capital/labor ratios with respect to Western Europe, reduced risk premia

${ }^{22}$ Credit from abroad is particularly important not only because it involves a rise in banks' resources available to finance private credit, but also because, to the extend that it leads to central bank foreign exchange intervention, it generates the base money without which the money multiplier could not work (see Section IV). 
Table 13. Fiscal Deficits: 2002-2005

(In percent of GDP) $)^{1}$

\begin{tabular}{|c|c|c|c|c|c|}
\hline \multirow[t]{2}{*}{$\mathrm{O}$} & \multicolumn{2}{|l|}{ utturn } & \multicolumn{3}{|c|}{ Targets } \\
\hline & 2000200120022003 & & & 2004 & 2005 \\
\hline Albania & 8.98 .56 .96 .6 & & & 6.0 & 5.8 \\
\hline Bosnia and Herzegovina & 10.05 .84 .32 .2 & & & 2.0 & 1.7 \\
\hline Bulgaria & 1.00 .90 .60 .7 & & & 0.5 & 0.0 \\
\hline Croatia & 6.56 .84 .84 .6 & & & $\ldots$ & $\ldots$ \\
\hline Czech Republic & 3.52 .94 .76 .3 & & & 5.7 & 5.5 \\
\hline Estonia & $0.4-$ & 1.2 & 0.0 & 0.0 & 0.0 \\
\hline Hungary & 3.04 .79 .54 .5 & & & 3.0 & 2.5 \\
\hline Latvia & 3.22 .22 .73 .2 & & & 2.9 & 1.9 \\
\hline Lithuania & 2.81 .91 .22 .0 & & & 2.7 & 2.1 \\
\hline Macedonia, FYR ${ }^{2}$ & -1.87 .24 .61 .6 & & & 2.5 & 2.9 \\
\hline Poland $^{3}$ & 3.33 .54 .04 .1 & & & 3.8 & 3.4 \\
\hline Romania & 4.03 .22 .62 .7 & & & 2.5 & 2.2 \\
\hline Serbia and Montenegro & 0.91 .44 .54 .5 & & & 4.3 & 3.9 \\
\hline Slovak Republic ${ }^{4}$ & 10.77 .37 .25 .1 & & & 3.9 & 3.5 \\
\hline Slovenia & 1.41 .41 .51 .2 & & & 0.9 & 0.7 \\
\hline Average $^{5}$ & 3.7 & 3.8 & 3.2 & 2.9 & 2.5 \\
\hline
\end{tabular}

${ }^{1}$ General government.

${ }^{2}$ IMF Staff projections for 2005.

${ }^{3}$ ESA95 basis. The figure for 2000 is estimated based on the change in the cash deficit during 2000-01.

${ }^{4}$ ESA95 basis.

${ }^{5}$ Excluding Croatia.

because of EU accessions, expectations of real exchange rate appreciation, and, in many countries, still sizable nominal interest rates differentials (Table 14). ${ }^{23}$

${ }^{23}$ Table 14 provides a rough estimate of the scope for capital inflows following the approaches, and updating the estimates, in Lipschitz, Lane, and Mourmouras (2002).

- The first two columns of the table relate to factors affecting financial investment. The first column is the uncovered interest rate differential, which has remained sizable in recent years. The second column reports the real interest rate that, assuming no risk premium, would equate the yield from financial investment in each CEB country and in Germany, assuming that the real appreciation in CEB countries observed during 19992002 continues over the next few years. This real interest rate is negative in most of the CEB countries suggesting that the pressure of capital inflows will have a strongly expansionary effect in the years ahead (assuming the risk premium declines as a result of EU entry and euro-proximity). 
Table 14. Factors Affecting Capital Inflows

\begin{tabular}{lccc}
\hline & $\begin{array}{c}\text { Nominal Interest Rate } \\
\text { Differential }^{1}\end{array}$ & $\begin{array}{c}\text { Parity Real Interest } \\
\text { Rate }^{2}\end{array}$ & $\begin{array}{c}\text { Estimated Capital } \\
\text { Gap }^{3}\end{array}$ \\
\hline Albania & 7.4 & 3.4 & 1131.1 \\
Bosnia and Herzegovina & 5.5 & -- & -- \\
Bulgaria & 1.3 & -2.1 & 707.9 \\
Croatia & 0.2 & -0.8 & 502.2 \\
Czech Republic & 1.1 & -2.8 & 224.1 \\
Estonia & 0.7 & -0.6 & 417.2 \\
Hungary & 7.8 & -6.8 & 282.6 \\
Latvia & 1.6 & 2.8 & 549.5 \\
Lithuania & 7.7 & -0.9 & 555.1 \\
Macedonia, FYR & 7.5 & -- & 898.8 \\
Poland 11.4 & & -2.7 & 427.5 \\
Romania 42.4 & & -14.6 & -- \\
Serbia and Montenegro & -- & -- & - \\
Slovak Republic & 5.5 & -4.3 & 347.7 \\
Slovenia & 6.3 & -0.2 & 157.7 \\
\hline Source: Appendia & & & \\
\hline
\end{tabular}

Source: Appendix I.

${ }^{1}$ Average differential during 1999-2002 between deposit rate (Croatia, Estonia, the Former Yugoslav Republic of Macedonia, and Slovenia) or t-bill rate (all other countries) in the reference country and the corresponding interest rate in Germany.

${ }^{2}$ Real interest rates in the reference country that would equalize domestic and foreign interest rates assuming the average real exchange rate appreciations observed in 1999-2002 continue.

${ }^{3}$ See text for definition.

- The third column estimates the real capital gap of CEB countries, and, thus, the potential for real investment from abroad. It is based on the following approach: in the absence of impediments to capital mobility, the yield from real investment would be equal across countries. CEB countries, however, are, at present, much less capital intensive than EU countries. Hence, a higher marginal yield from investing in CEB countries than in the EU. Assuming a common Cobb-Douglas production function, one can thus compute the capital flows necessary to equalize the yield from real investment in CEB countries and, say, Germany, so that the following equilibrium conditions, i.e., the capital-labor ratio of CEB countries equals that of Germany, holds:

$$
\frac{k_{i}^{*}-k_{i}}{y_{i}}=\frac{k_{g e r}-k_{i}}{y_{i}}=\frac{k_{g e r}}{y_{g e r}} \frac{y_{g e r}}{y_{i}}\left(1-\left(\frac{y_{i}}{y_{g e r}}\right)^{\frac{1}{\alpha}}\right)
$$

where $\alpha$ is assumed to be equal to $1 / 3, y_{i}$ is the per capita output in country $i, \mathrm{k}_{i}$ is the capital-labor ratio in country $i$, and $\mathrm{k}_{\text {ger }}$, the German capital-output ratio, is set at 1.74 , as estimated in the Penn World Tables. Table 14 reports the capital gap, in percent of GDP, computed from this equilibrium condition. 


\section{Macroeconomic Implications of Fast Bank CRedit Growth}

Does an increase in the BCPS ratio have macroeconomic implications? Does it signal that demand is rising faster than supply or, more generally, that the economy may be overheating? Answering these questions is not straightforward because, unlike the demand for money, the demand for credit has not been a subject of intense theoretical discussions. While we have mainstream theoretical models of money demand and its relationship with GDP, analytical work on the demand for credit is more limited. Indeed, the ModiglianiMiller theorem, at face value, would imply that the output elasticity of credit is indeterminate, as firms' production decisions should not be affected by the structure of their balance sheet. At the empirical level, however, several macroeconometric models do include demand for credit equations. But there is no presumption that the elasticity of credit with respect to output should be equal to one, i.e., that the "credit velocity" should be constant. ${ }^{24}$

While a mainstream theory for the demand for credit — and a fortiori for the demand for a particular form of credit, namely bank credit - is still missing, it is clear that a rising loans to GDP ratio should not per se be taken as a sign of economic overheating. Even in a simplified model in which all increase in credit finances additional demand, a rise in credit faster than the potential growth rate of the economy is not a sign that demand is rising faster than potential. Consider the simplified case in which aggregate demand is formed by two components: "investment" (which is financed entirely through bank loans) and "consumption", which is a constant fraction of income (and overall demand is equal to overall income):

$\mathrm{Y}=\mathrm{I}+\mathrm{cY}=\Delta \mathrm{L}+\mathrm{cY}$

where $\mathrm{Y}$ is demand and income, $\mathrm{I}$ is investment, and $\mathrm{L}$ is the stock of bank loans. As the growth rate of consumption is equal to the growth rate of Y, demand growth can exceed that of potential output $(\mathrm{g})$ only if the rate of growth of investment $(\lambda)$ exceeds potential output growth (which we take independent from investment). In this model, a rise in the loan to GDP ratio involves that $\mathrm{Y}$ is rising faster than potential only if:

\footnotetext{
${ }^{24}$ These models often include equations linking the credit stock to the GDP level or industrial production. A recent model following this approach is presented in Calza, Gartner and Sousa (2003), who find an elasticity of credit demand to GDP well above one.
} 


$$
\frac{L_{-1}}{Y_{-1}}>\frac{1+g}{\lambda}
$$

Thus, a rise in the loan-to-GDP ratio would signal an overheating, only if the initial stock of loans were sufficiently large in relation to GDP, or if the growth rate of the demand component financed by loans is sufficiently large compared to the potential growth rate. ${ }^{26}$

In sum, there should be no presumption that a rise in the BCPS ratio implies that the economy is overheating. In this respect, the different experiences during 2002 of Bosnia, Serbia and Montenegro, and Croatia, on the one hand, and Bulgaria, on the other hand, are remarkable: In the first three countries a surge in credit in 2002 was matched by a sharp deterioration of the external current account, while in the latter the credit acceleration had no obvious macroeconomic implications.

At the same time, it is clear that changes in the behavior of banks of the kind that we have observed in the last few years in CEB countries and that are likely to be observed in the future, will have expansionary effects that policy-makers cannot disregard. Two main and distinct channels would, in principle, be at play: (i) an increased propensity of banks to lend (due to microeconomic factors discussed earlier), given the monetary base; and (ii) an increase in capital inflows through banks (an overall monetary expansion, assuming some foreign exchange intervention by the central bank; see below). The effects on aggregate demand, interest rates, bank loans and bank deposits of these changes can conceptually be analyzed through a simple IS-LM model (augmented by a banking sector flow of funds model) in which some part of private spending requires to be financed by bank loans. In such a model, even in the absence of an increase in base money, an increased propensity of banks to lend has expansionary effects on aggregate demand and the stock of bank loans, essentially because it lowers the cost of borrowing from banks with respect to the market interest rate on bonds (a shift to the right in the IS curve). ${ }^{27}$ However, in the absence of an

${ }^{25}$ This assumes that the actual growth of GDP is equal to demand, i.e., that it may differ from potential growth.

${ }^{26}$ Moreover, not the whole increase in lending necessarily finances additional demand. Loans can be extended to finance, for example the purchase of existing real estate, or other assets. If sellers deposit in banks the receipts from the real asset sales, deposits and loans increase by the same amount with no change in aggregate demand (although there may be second order wealth effects as a result of rising real estate prices, as well as risks from asset price bubbles; see Section V).

27 The effect of a shift in the supply of bank loans (and of the IS curve) to the right has, however, an ambiguous effect on the stock of bank deposits and, at least in principle, on the 
increase in base money (or of an initial stock of excess reserves of banks), the expansionary effects in this model depend on the elasticity of base money demand to interest rates. If this is low, an increase propensity of banks to lend has little effects on aggregate demand: it simply raises the level of interest rates (the LM would be vertical).

There is not much information on the elasticity of the demand for base money in CEB countries. However, as noted above, in CEB countries the secondary liquidity of banks (short-term central bank assets and deposits held abroad) is not trivial. Banks can repatriate their holdings of foreign exchange held abroad or reduce their holdings of central bank paper. In such a scenario, other things being equal (that is, assuming no reaction by the central bank, in the context of a stable exchange rate), the shift to the right of the supply curve of bank deposits would be accompanied by an increase in base money and its effect on aggregate demand would be magnified. In this respect, the experience of CEB countries in the years ahead - or at least the experience of those CEB countries that are relatively closer to euroadoption - may turn out to be similar to that of countries "at the periphery of pre-euro Europe" in the late 1990s, i.e., of those countries that, on their way to the euro, had not yet converged, in terms of inflation and interest rate performance, to the performance of "core" countries. ${ }^{28}$ In most of these countries, in spite of the accompanying sizable fiscal tightening, the convergence of interest rates to "core" European levels was matched by a surge in bank loans and a widening of the external current account deficit (Figure 4).

The authorities have essentially at their disposal five instruments to respond to a surge in BCPS and aggregate demand: standard monetary policy tools; fiscal policy; controls on capital inflows; administrative credit ceilings; and supervisory measures. ${ }^{29}$ In practice, in recent episodes of fast credit growth in CEB countries, the authorities have resorted to a combination of these tools, rather than relying on a single policy response.

stock of government bills held by banks. The reason is that the increase in income raises the demand for bank deposits. The latter, however, is depressed by the increased demand for government bills as bond rates rise, so the result is indeterminate. Because of this uncertain effect on deposits, such a model could not predict what happens to the demand for bonds by banks and (hence) by households.

${ }^{28}$ A detailed discussion of the experience of these countries in the run up to the euro introduction at the end of 1998 is included in Schadler and others (2003), from which Figures 4 is reproduced.

${ }^{29}$ In addition, the government can remove distortions that cause an otherwise unjustified growth in credit. A case in point is the subsidy scheme on housing in Hungary (the removal of which would moderate the demand for housing and mortgage credit) and the existing subsidized credit schemes in Croatia. 


\section{Figure 4. Private Sector Credit, Real Interest Rates, and External Current Account Before Euro’s Adoption}
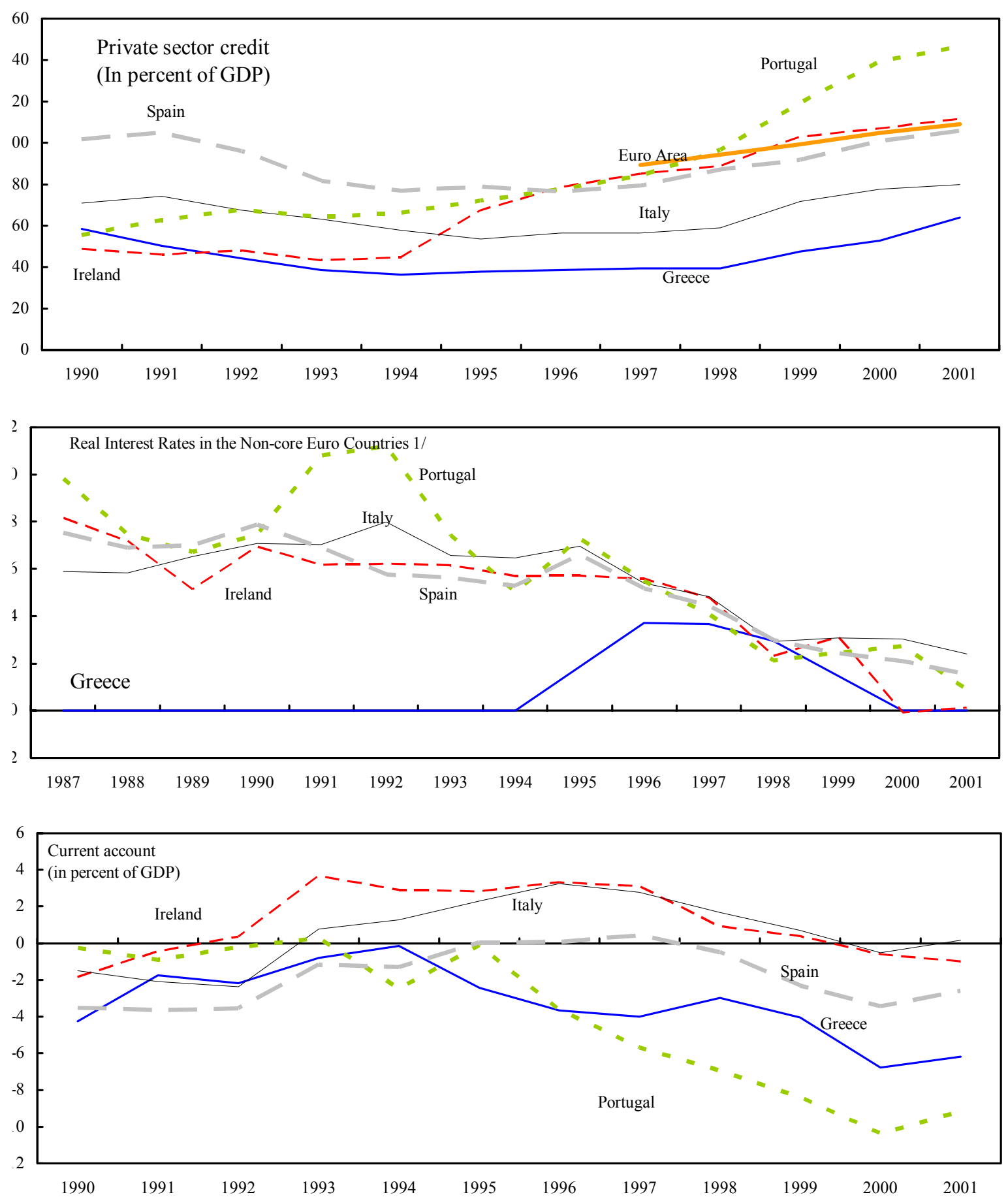

Sources: Organization for Economic Cooperation and Development; International Financial Statistics; and IMF staff calculations.

1/ Long-term rates refer to 10-year benchmark bond yield. Deflated by CPI inflation. 


\section{A. Monetary Policy}

In principle, overheating pressures could be offset, first and foremost, through open market operations or equivalent measures to contain base money growth, including to offset a shift of banks out of their (base money-creating) secondary liquidity. With the exclusion of Bulgaria, Bosnia and Herzegovina, Estonia, and Lithuania (which have currency boards in place), almost all other CEB central banks have available now one or more money market instrument to control liquidity. Thus, responding to a one-off disturbance in the liquidity market (like a fall in the demand for primary liquidity or in base money-creating secondary liquidity) should, in principle, be possible, no matter how sizable it is.

In practice, the feasibility of this approach will depend, in the context of a fairly stable exchange rate, on the elasticity of foreign capital inflows to domestic interest rates, i.e., on the extent of capital mobility. If this is high, the central bank's efforts to raise money market interest rates in response to an increase supply of bank loans will be frustrated. What is the evidence in this respect? Can sterilized intervention work for CEB countries? Obviously, the response would have to be different depending on the degree of integration of each country with the rest of the world. The effectiveness of sterilized intervention in the CEB area has been studied only by a handful of papers, mostly focusing on the Hungarian and Czech experiences during the second half of the 1990s. These studies generally found offset coefficients that are well below unity, signaling the effectiveness of sterilized intervention in the short run. ${ }^{30}$ Most studies, however, point at the financial cost that sterilized intervention has over time (see, for example, Neményi, 1996, and Barabás, Hamecz, and Neményi , 1999) and at the fact that, to the extent that it is effective in keeping domestic interest rates higher than abroad, sterilized intervention perpetuates capital inflows, and, thus, leads to the building up of a stock of short-term assets that can suddenly move abroad, or be used to fuel domestic credit growth (Begg, 1998). Indeed, as discussed above, sterilized intervention in some CEB countries has indeed allowed banks to build up large secondary liquidity reserves that could potentially fuel credit growth (or a speculative attack against the currency).

It is important to keep in mind that, whatever the elasticity of capital inflows in the 1990s and thus the scope for (short-run) sterilized intervention, this scope is likely to have declined significantly for the countries that are now close to EU accession. While a detailed discussion

${ }^{30}$ For the Czech Republic: Begg (1998) refers to offset coefficients published in earlier studies of $1 / 3-2 / 3$; Christensen (2003) finds a coefficient below 0.15; OECD (1996) refers to a coefficient range of 0.4-0.65 estimated by the Czech National Bank. For Hungary, Fernández-Ansola and Moghadam (1996) find an offset coefficient of 0.5 for the period preceding March 1995, when the crawling-per was introduced. However, for the period following the introduction of the crawl they find a coefficient close to unity, but with a large standard error. 
of this issue would go beyond the scope of this paper, enough it is to recall that during 1996 - a year when sterilized intervention was particularly strong in Hungary - the net domestic assets of the central bank declined by some US\$5 billion, mostly reflecting sterilization of inflows during that year. In contrast, during the speculative attack of January 16, 2003 the purchases of foreign exchange by the National Bank of Hungary (which were not sterilized at that time) amounted to several billions of U.S. dollars in a single day.

This obstacle (the high elasticity of capital inflows to interest rates) would not prevent using the monetary policy lever in countries which were willing to accept a sizable exchange rate appreciation. However, some CEB countries have clearly stated their preference for exchange rate stability. ${ }^{31}$ More generally, two factors are likely to make CEB countries unwilling to accept easily strong appreciations. First, the underlying external current account position for these countries is likely to be in deficit, and countries, particularly those with sizable gross external debt, may be unwilling to see the external deficit widen further as a result of an appreciation, given uncertainties on the sustainable external deficit. Second, there is a risk of non-reversibility of an exchange rate appreciation for those countries that are on their way to euro-adoption. This risk stems from the fact that the market exchange rate may be used as the entry rate in the area, thus possibly "freezing" an overvalued exchange rate position.

\section{B. Fiscal Policy}

Fiscal policy is the obvious policy tool to avoid overheating when, in the presence of high capital mobility, monetary policy is constrained by the desire to avoid an exchange rate appreciation (Lipschitz, Lane and Mournouras, 2002; Schadler et al., 2003). The "good news" here is that many CEB countries are still running fairly sizable deficits: indeed, in 200260 percent of the countries in our sample had a general government deficit of over 4 percentage points of GDP (Table 13), above the Maastricht Treaty ceiling and, a fortiori, above the balanced budget medium-term fiscal target that is required by the current formulation of the Stability and Growth Pact. The fact that a fiscal tightening would be consistent with the medium-term fiscal consolidation path will facilitate its use in response to overheating pressures. In this respect, the experience of CEB countries is different from that of Asian countries in the run-up to the late 1990s crises. The latter had "a strong track record of low ... fiscal positions that had, on average, been close to balance (Indonesia, Korea, and Philippines) or in surplus (Thailand)" (Ghosh and others, 2002, p. 5).

Nevertheless, it remains to be seen whether, in practice, countries will stand ready to tighten fiscal policy promptly and sufficiently to avoid overheating. The governments of Croatia,

${ }^{31}$ In addition to the four countries with currency board, Latvia is pegging its exchange rate, and Macedonia (formally a managed float) has maintained a de facto peg. The Croatian authorities have also repeatedly stated their intention to keep the exchange rate broadly stable, while allowing for short term fluctuations. 
Bosnia and Herzegovina, and Serbia and Montenegro did regard the fast credit growth and a rapidly widening external current account deficit as a sufficient reason to tighten fiscal policy in 2003. In two of these countries, however, and in the run-up to general elections, the fiscal response was small (Table 13). ${ }^{32}$ In all of them, the countries authorities relied also on monetary policy instruments, including of an administrative nature. ${ }^{33}$

\section{Capital Controls}

Capital controls have been removed in most of CEB countries (Table 15). Their reintroduction is at odds with long-term commitments towards freedom of capital mobility arising from OECD and EU membership. Nevertheless, at least in principle both OECD and EU rules do not seem to be inconsistent with the temporary reintroduction of controls on capital inflows. ${ }^{34}$ The matter is, rather, a practical one. First, whether these controls would be effective in a world in which financial transactions are increasingly sophisticated. Evidence on this is mixed, but it should not be taken for granted that such controls would generally be largely ineffective. Second, whether the reintroduction of controls would not be seen as a step back in the transition process. Concerns of this type may reduce the attractiveness of capital controls in many CEB countries.

\section{Credit Ceilings}

Bank-by-bank credit ceilings - usually involving a penalty in the form of mandated investment at below market interest rates for banks with high credit growth-were a common monetary policy tool in the 1960s and 1970s. At that time, their main rationale was to ensure an effective control of credit growth (and hence aggregate demand) in the absence of a smoothly functioning monetary policy transmission mechanism, or to affect credit growth and aggregate demand without causing a generalized increase in interest rates, particularly on government paper.

${ }^{32}$ In the case of SM, eventually, there was no tightening as the 2002 fiscal outturn was better than expected when the 2003 budget was formulated.

${ }^{33}$ Credit ceilings in Croatia; a rise in reserve requirements in $\mathrm{BiH}$ and $\mathrm{SM}$.

${ }^{34}$ According to Articles. 119-120 and 122 of the Treaty on European Union, countries with a derogation (that is EU members that have not yet adopted the euro) are allowed, with the authorization of the EU commission, to take "protective measures" in case of difficulties affecting the balance of payments. This definition seems to be wide enough to cover the introduction of controls on short-term capital inflows that are fueling an unsustainable deterioration in the external current account. Regarding the OECD, Article 7 of the Capital Movements Code allows OECD members to suspend capital mobility for up to eighteen months if "the balance of payments ... develops adversely at a rate and in circumstances, including the state of its monetary reserves, which is considered serious." 
Table 15. Controls on Capital Inflows, Excluding Real Estate Purchases

\begin{abstract}
Albania No controls
Bosnia and No controls

Herzegovina
\end{abstract}

Bulgaria No controls, although there are some registration requirements

Croatia Controls on purchases of short-term securities (to be removed four years after the coming into effect of the Stabilization and Association Agreement with the EU). The central bank can also introduce short-term "safety measures" if capital movements cause or threaten to cause "serious difficulties in the implementation of monetary or foreign exchange policies."

Czech Rep. No controls

Estonia No controls

Hungary No controls

Latvia No controls

Lithuania No controls

Macedonia, There are fees on the purchase of short-term securities by nonresidents FYR

Poland No controls

Romania Nonresidents are not allowed to purchase t-bills and, in principle, other money market instruments

Serbia and Purchases of securities by nonresidents are restricted

Montenegro

Slovakia No controls

Slovenia No controls 
These considerations may, at least in principle, be still relevant in less advanced CEB countries. But, in more advanced countries credit ceilings may be appealing for a different reason. In today's world of high capital mobility, credit ceilings may be considered by CEB countries that - unwilling to allow the exchange rate to appreciate and, thus, unable to tighten domestic monetary condition in the presence of an open capital account - wish to constrain domestic credit growth. ${ }^{35}$

Credit ceilings were temporarily reintroduced in Greece in response to strong capital inflows, stimulated by Greece's expected entry in the euro-zone in 1999. They have, more recently, been imposed in Croatia in early 2003 following a surge in BCPS, also in the context of strong capital inflows.

The effectiveness of credit ceilings has not been subject to the same degree of scrutiny as capital controls. The few available study (Cottarelli et al. (1986)) conclude that, when effective (that is, when they are not circumvented), they significantly distort bank competition and are, thus, damaging for banking market efficiency - and, in this respect, should be seen as inferior to controls on capital inflows. For this reason, and, more generally, to avoid forms of financial dirigisme that may be seen as reminiscent of planning, credit ceilings are unlikely to become a permanent feature of CEB countries, although they may be occasionally used in response to credit booms.

\section{E. Prudential Instruments}

Prudential instruments potentially include: (i) pro-cyclical capital requirements; (ii) restrictive rules on collateral; and (iii) higher provisioning for banks with high credit growth. Prudential instruments, while similarly based on administrative intervention, differ from credit ceilings because the latter force banks with excessive credit growth to invest in assets bearing a below market yield, thus potentially reducing the solidity of the banks, while prudential tools aim also at increasing the solidity of banks. Prudential instruments have, thus, the advantage of addressing not only the macroeconomic aspects of credit booms, but also the prudential aspects. Indeed, prudential regulation has been strengthened-and on sight supervision intensified - in response of credit booms in a number of CEB countries (including, Bosnia and Herzegovina, Croatia, Serbia and Montenegro).

\section{Fast Credit Growth and Financial Stability}

Several observers have expressed concern about the effect for financial stability of the credit growth in CEB economies. For example, the IMF board has in several occasion cautioned

${ }^{35}$ For credit ceilings to be effective in this case, it would, of course, be necessary that bank customers cannot borrow directly from abroad. 
CEB countries against the risks for the quality of bank portfolios associated with a too rapid growth in private sector credit, and called for increased supervisory attention. ${ }^{36}$ In the background to these concerns was the ample evidence, from other countries' experiences, of an association between lending booms and banking crises. In what follows, after reviewing briefly the existing literature on the topic, we examine whether the recent expansion in BCPS in the CEB area qualifies as a credit boom.

\section{A. Lending Booms and Banking Crises: A Brief Review of the Literature}

A growing literature has documented that episodes of financial distress are likely to follow periods of strong credit expansion. As reported in Goldfajn and Valdes (1997) and Drees and Pazarbasioglu (1998), strong credit growth was observed before most banking crises. Argentina 1980; Chile 1982; Sweden, Norway, and Finland 1992; Mexico 1994; and Thailand, Indonesia, and Korea 1997 are the most significant examples. In some, but not all cases, fast credit growth was spurred by the deregulation of the financial sector that increased bank competition and/or granted access to the credit markets to new subjects. These reforms were also often accompanied by a reduction in banks' reserve requirements and by various degrees of capital account liberalization that provided the liquidity to fund the lending booms.

Several econometric studies have confirmed the existence of a link between rapid credit growth and banking system fragility. Demirgüç-Kunt and Detragiache (1997) find evidence supporting the idea that lending booms precede banking crises. For example, according to their estimates, in the case of 1994 Mexican crisis, a 10 percent increase in the initial value of lagged credit growth would have increased the probability of a crisis by $5 \frac{1}{2}$ percent. Similarly, Hardy and Pazarbasioglu (1998) find that there is a robust evidence that credit to the private sector follows a boom-and-bust pattern ahead of banking crises. Kaminsky and Reinhart (1999) find that the growth rate of the BCPS ratio accelerates markedly as banking crises or twin crises (banking and currency crises) approach, remaining well above the growth rate recorded in tranquil times. Finally, Gourinchas, Valdes, and Landerretche (1999) examine a large number of episodes characterized as lending booms and find that the probability of having a banking crisis significantly increases after such episodes. Moreover, the conditional incidence of having a banking crisis depends critically on the size of the boom. Nevertheless, they remark that such probability remains below 20 percent indicating that while most banking crisis may be preceded by lending booms, most lending booms are not followed by banking crises.

Triggered in part by these empirical findings, a number of recent theoretical models have examined the link between credit booms and banking crises. Most of these models

${ }^{36}$ See, for example, the Public Information Notices (PINs), available on the IMF website, relative to 2001 Article IV Consultation with Latvia, the 2002 Article IV Consultations with Bulgaria and Croatia, and the 2003 Article IV Consultation with Estonia and Hungary. 
incorporate some form of financial accelerator based on the role of collateral requirements. ${ }^{37}$ Typically, some exogenous shock increases the value of the asset used for loan collateralization. This leads to a rise in credit, as borrowers' new wealth relaxes their credit constraint. More credit, in turn, leads to further increases in asset demand and prices, further relaxing borrowers' credit constraint, and so on. In this context, banks and bank regulators with scarce resources may find it more difficult to screen and monitor borrowers properly. Furthermore, adverse selection associated with the superior information each bank has about its own clients decreases leading to a further decrease in borrowers screening (Dell'Ariccia and Marquez, 2003). All in all, the "excessive" pace of credit growth leads to a deterioration of the quality of bank portfolios. When the bubble bursts, either because of an exogenous shock or because of the failure of a large number of the "bad" projects funded during the boom, the whole process is reversed. Borrowers unable to repay their debt see their collateral seized and sold by the banks. Asset prices decline rapidly depleting the value of the collateral and triggering further loan recalls, etc. This credit crunch then leads to a contraction in investment with negative effects for the real economy.

A different literature (see, for recent examples, Rajan and Zingales, 1998; Beck, Levine, and Loayza, 2000; and Levine, Beck, and Loayza, 2001), emphasizing the link between financial development and growth, has suggested a more positive vote for credit booms. According to this view, the financial sector plays a fundamental role in the allocation of savings to productive enterprises, favoring economic efficiency and capital accumulation. In that context, rapid credit growth can, then, be simply the result of a financial deepening that will eventually benefit the economy. Therefore, as Gourinchas et al. (2001) point out, some of these fast lending phases may represent permanent shifts rather than transitory cycles. It follows that the policy response to rapid credit growth should depend on whether one expects the episode to be a transitory boom or a permanent shift.

\section{B. Detecting Lending Booms in CEB Countries}

Can the rapid credit growth observed in CEB countries be characterized as a credit boom with implications for financial stability? As a preliminary test it is useful to compare the growth of the BCPS ratio in CEB countries with that of a group of countries on their way to experience a banking crisis (Figure 5). The differences are significant. In the years preceding their banking crises most countries in our control group experienced annual increases in the BCPS ratio often exceeding 5 percentage points, and sometimes as high as 10 percentage points. On the contrary, in CEB economies, these increases are generally around 2 percentage points and only in a few cases have exceed 5 percentage points. Moreover, the initial level of the BCPS ratio was much higher in the control group. This in no way rules out the possibility of future problems - there were crisis countries with relatively low rates of growth of credit - but should put the issue of the "fast" pace of credit growth in the right perspective.

${ }^{37}$ See Kiyotaki and Moore (1997) and Aghion, Bacchetta, and Banerjee (2001). 
Figure 5. BCPS Ratios in Bank Crisis Countries and Early Birds
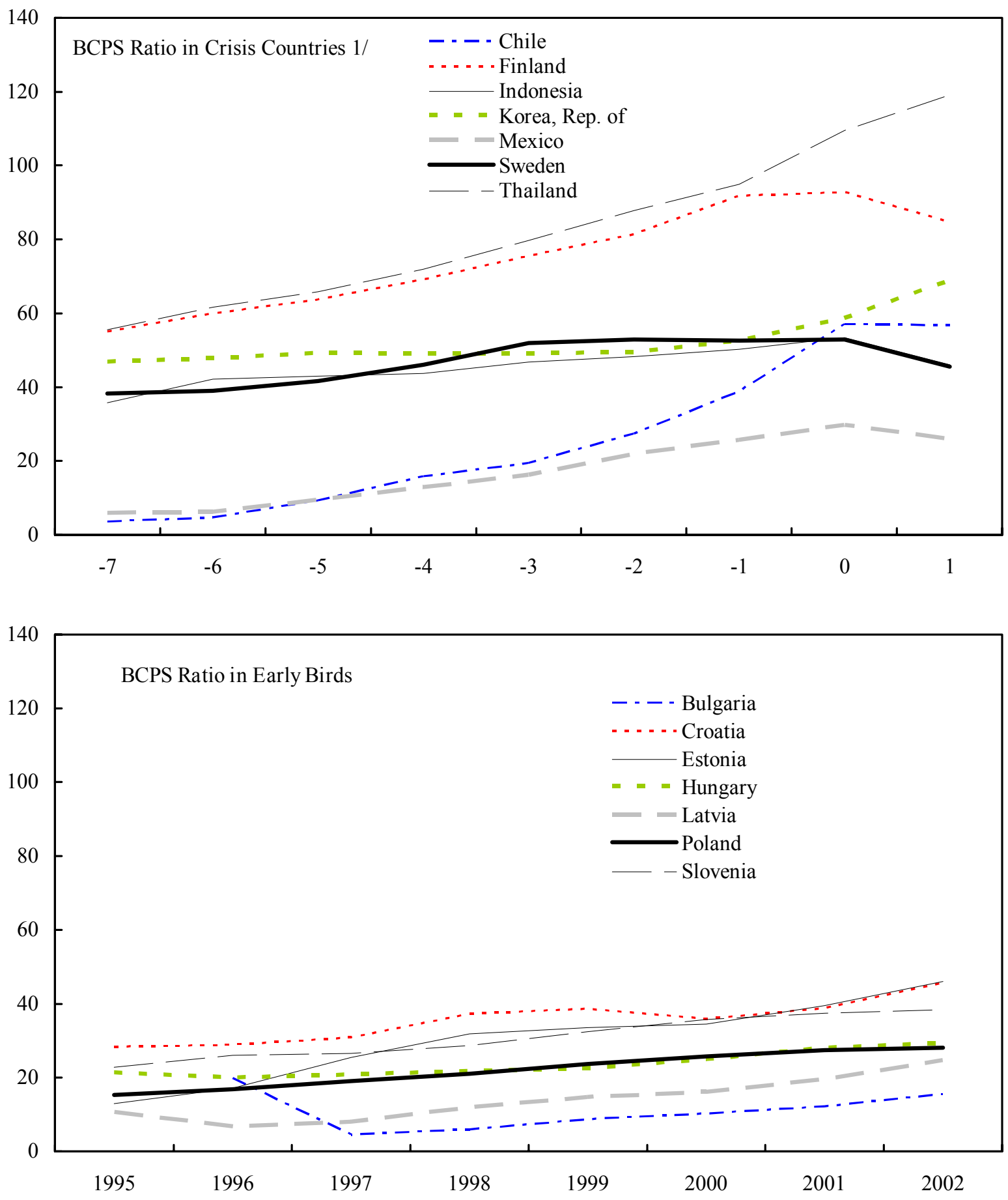

Source: Appendix I.

1/ Year 0 is the crisis year. 
In order to examine more formally the evolution of the BCPS ratio in CEB countries, we apply the methodology developed in Gourinchas et al. (2001). In their paper, a lending boom is defined as an episode where the BCPS ratio deviates from a rolling, backward-looking, country-specific stochastic trend (estimated by an Hodrick-Prescott filter). The idea is that such stochastic trend represents the historically "normal" pace of credit growth for each particular country. This methodology has the advantage that to construct a rolling backwardlooking trend one needs only the information available up to the time period that needs to be evaluated. This allows us to examine the evolution of bank credit also for the very recent past. Obviously, this methodology does not allow us to predict what will happen to a lending boom episode. Indeed, as noted, some lending booms may be part of long term process of financial deepening. Nevertheless, to the extent that most banking crises are preceded by lending booms, this approach provides useful information for assessing whether or not a lending boom is in progress.

A few caveats specific to our case are also granted. The first is that one should keep in mind that the short range of all these BCPS time series makes the results very sensitive to individual observations. Second, the idea of comparing the actual realization of the BCPS ratio with a backward-looking rolling trend is based on the notion that such a trend component represent the "normal" level of the ratio in any given point in time. However, since all the countries in our sample are transition economies that by definition have not experienced "tranquil times" in the recent past, one could argue that the HP filter of past realizations of the BCPS ratio does not represent for these countries a proxy for what such ratio should be expected to be. ${ }^{38}$ With these caveats, we now turn to examine the presence of lending booms in our sample.

Based on the BCPS data used in the earlier sections, we construct for each country in our sample the backward looking stochastic trend for the BCPS series, for each year in the sample, by applying an HP filter using data from the beginning of the sample to that particular year. ${ }^{39}$

Gourinchas et al. (2001) propose two criteria to evaluate deviations from trend. The first is to consider the relative deviation of the actual from the predicted BCPS ratio. This measure

\footnotetext{
${ }^{38}$ This can lead both to an overestimation and an underestimation of credit booms. For at least some of the countries, in the early years the observed decline in the BCPS ratio may be affected by write-offs, which make it harder to identify the underlying credit trend. This problem may lead to the overestimation of credit booms, as it tends to exaggerate the importance of a pick-up in credit with respect to previous trends (a case in point is Bulgaria; see below). Conversely, however, this approach can underestimate credit booms, as it detects anomalies only as deviations from trends, rather then from the slope of the trend, even if the latter is very steep (see the case of credit to households in Latvia, below).

39 The first five years of data are used to construct the first trend.
} 
compares the size of the deviation to the size of the banking sector, and therefore it does not depend on the degree of financial development in the country. The second measure considers the absolute deviation of actual from predicted BCPS ratios and, thus, depends on the degree of financial deepening, as countries with larger BCPS ratios are more likely to experience sizeable absolute deviations from trend.

Table 16 reports the BCPS ratio and its trend component for 2002, together with the absolute and relative deviations. The table broadly confirms the classification of CEB countries that we proposed in Section II. In 2002, all early birds, but Slovenia, had BCPS ratios in excess of their trend component; while most sleeping beauties experienced negative or close to zero deviations. Notably this is true also for countries characterized by relatively more developed financial systems such as the Czech Republic and the Slovak Republic. Lack of consistent data prevented the computation of the trend component for Bosnia and Herzegovina and Serbia and Montenegro.

Since any series experiences deviations around its stochastic trend, one needs to choose a threshold beyond which a positive deviation from trend should be classified as a lending boom. This choice is necessarily an arbitrary one. Gourinchas et al. (2001) employ different thresholds ranging from 4.8 percent to 6.4 percent for the absolute deviations, and from 24.9 percent to 31.1 percent for the relative ones. According to those boundaries, only one CEB lending boom could be detected in 2002. Bulgaria had a relative deviation of 24.1 percent that is slightly below the lower bound of the threshold range. For all the other countries, even the most generous of the definitions in Gourinchas et al. (2001) misses to classify the rise in the BCPS ratio in 2002 as a lending boom (although Latvia is a close call).

A closer examination of the case of Bulgaria reveals that the current "boom" is, at least in part, the result of a rebound from a period of continued and/or severe credit contraction. Bulgaria experienced a severe banking crisis in 1997 with the consequent reduction of the BCPS ratio from 20 percent to below 5 percent. The 2002 level is still well below the pre1997 level and among the lowest in our group of countries. Furthermore, the BCPS ratio in Bulgaria is still below its "equilibrium" level, as estimated in the model in Section III. It is, then, difficult to rule out that for Bulgaria the recent rapid pace of credit growth is the result of a combination of "catching-up" and medium-run financial deepening, rather than part of a boom-bust episode.

Observers stressing the risks associated with credit booms have often focused on credit flowing to particular sectors of the economy, such as mortgage lending or consumer lending. A fast credit expansion in a particular sector can occur through a reallocation of bank portfolios, even in the absence of an aggregate credit boom. From a prudential supervision standpoint, these sectoral booms may entail risks that are similar to those associated with aggregate booms. Indeed, banks may find their monitoring and screening resources stretched 
Table 16. BCPS Deviations From Trend, 2002

\begin{tabular}{lcccr}
\hline \multicolumn{1}{c}{ Country BCPS } & Ratio (a) & $\begin{array}{c}\text { HP-Estimated } \\
\text { BCPS Ratio (b) }\end{array}$ & $\begin{array}{c}\text { Absolute } \\
\text { Deviation (a-b) }\end{array}$ & $\begin{array}{c}\text { Relative Deviation } \\
\text { (a-b)/a in Percent) }\end{array}$ \\
\hline Bulgaria 15.6 & & & & 24.1 \\
Croatia & 45.6 & 41.8 & 2.5 & 4.7 \\
Estonia & 46.0 & 45.6 & 0.4 & 1.0 \\
Hungary 29.3 & & 26.0 & 3.3 & 11.2 \\
Latvia 24.8 & 28.1 & 20.4 & 4.4 & 17.6 \\
Poland & & 27.1 & 1.0 & -1.7 \\
Slovenia 38.4 & & 39.0 & -0.6 & 19.7 \\
& & & & \\
Lithuania 14.2 & & 11.4 & 2.8 & 14.3 \\
& & & & -6.2 \\
Albania & 4.9 & 4.2 & 0.7 & 6.9 \\
Czech Republic & 42.6 & 45.2 & -2.6 & -5.6 \\
Macedonia, FYR & 17.1 & 15.9 & 1.2 & -16.3 \\
Romania 8.3 & & 8.8 & -0.5 & \\
Slovak Republic & 31.5 & 36.6 & -5.1 & \\
& & & & \\
\hline
\end{tabular}

Source: Appendix I.

thin when expanding in previously little explored market segments. Furthermore, "excessive" credit to particular sectors of the economy may result in macroeconomic imbalances and lead to asset price bubbles. More specifically, mortgage loans can fuel an asset price bubble, while consumers' credit can lead to an expansion of demand not matched by a rise in potential output. ${ }^{40}$ Both these forms of credit are likely to be key components of credit to households. It thus makes sense to study more carefully developments in credit to this sector. $^{41}$

The examination of data on bank credit to households reveals a picture that is slightly different from that obtained from aggregate data. (Table 17). For these data, absolute deviations of the Credit-to-Household-to-GDP ratio (BCH ratio) from trend are uniformly

${ }^{40}$ A more direct analysis of asset prices, and real estate prices in particular, would be useful but is severely limited by data availability. See Kiss (2002) for an analysis of recent developments on the Hungarian real estate market.

${ }^{41}$ Admittedly, credit to households includes, in some countries, also credit to small enterprises, and, thus, does not necessarily fully finance consumption or house purchases. Data availability does not allow further investigations of disaggregated credit developments. 
Table 17. BCH Deviations From Trend, 2002

\begin{tabular}{llccc}
\hline \multicolumn{1}{c}{ Country BCH } & Ratio & $\begin{array}{c}\text { HP-Estimated } \\
\text { BCH Ratio (b) }\end{array}$ & $\begin{array}{c}\text { Absolute } \\
\text { Deviation (a-b) }\end{array}$ & $\begin{array}{c}\text { Relative Deviation } \\
(\mathrm{a}-\mathrm{b}) / \mathrm{a} \text { in Percent })\end{array}$ \\
\hline & & & & \\
Bulgaria & 3.2 & 3.1 & 0.1 & 1.7 \\
Croatia 20.5 & & 19.1 & 1.4 & 6.7 \\
Czech Republic & 6.9 & 5.7 & 1.2 & 17.9 \\
Estonia 10.4 & & 9.7 & 0.6 & 6.2 \\
Hungary & 6.8 & 4.4 & 2.4 & 34.9 \\
Latvia & 6.25 .40 .8 & & & 12.3 \\
Macedonia, FYR & 2.0 & 1.8 & 0.2 & 10.8 \\
Poland 11.2 & & 11.6 & -0.4 & -3.3 \\
Romania & 0.70 .50 .2 & & & 22.4 \\
Slovak Republic & 5.3 & 4.5 & 0.8 & 15.6 \\
Slovenia 10.9 & & 12.5 & -1.6 & -15.0 \\
& & & & \\
\hline
\end{tabular}

small. This is not surprising since in pre-transition economies credit to individuals has been typically underdeveloped, as banks traditionally focused on funneling finance to large stateowned enterprises. Indeed, for all countries in our sample, but Croatia, credit to households represents only a small percentage of GDP. Relative deviations are, instead, sizable. These ratios are consistent with the presence of a boom in credit to households in Hungary, which has a $\mathrm{BCH}$ ratio well in excess of the 24 percent threshold. In this country, large and consisted deviations have been observed since 1988 (Table 18). The Czech Republic and Romania also have high ratios but fall below the test threshold.

Table 18. Hungary: Deviations of BCH Ratio from Rolling Trend

\begin{tabular}{|c|c|c|c|c|}
\hline Year B & $\mathrm{CH}$ & $\begin{array}{l}\text { HP-Estimated } \\
\text { BCH Ratio (b) }\end{array}$ & $\begin{array}{c}\text { Absolute } \\
\text { Deviation (a-b) }\end{array}$ & $\begin{array}{l}\text { Relative Deviation } \\
\text { (a-b/a in Percent) }\end{array}$ \\
\hline 1999 & 2.72 .00 .7 & & & 24.1 \\
\hline 2000 & 3.52 .41 .1 & & & 32.1 \\
\hline 2001 & 4.83 .11 .6 & & & 34.5 \\
\hline 2002 & 6.84 .42 .4 & & & 34.9 \\
\hline
\end{tabular}

Furthermore, the examination of the data on credit to household reveals one of the limits of the approach based on the HP filter with short time-series. In the past two years, six other countries, Bosnia, Bulgaria, Croatia, Estonia, Latvia, and Macedonia experienced high growth rates in $\mathrm{BCH}$. Although these were often in excess of 20 percent, they were not picked up by our test as credit booms because of the short data series and the relative stability of credit growth. This strong growth was incorporated in the trend component and, thus, did 
not show up in the deviation from trend. Of course, this does not necessarily mean that these countries are not currently experiencing a boom in credit to households. ${ }^{42}$

In summary, the recent evolution of bank credit relative to its trend component in CEB countries does not reveal a particularly troublesome picture. Nevertheless, these results should be interpreted with caution. First, the very short span of our dataset limits, severely, the power of the test, as strong credit growth may end up in the trend component, if it is stable over a few years. Furthermore, our analysis focused primarily on overall credit trends and disregarded important factors that affect credit risk and the fragility of the banking system, such as the currency composition of bank and corporate balance sheets, maturity mismatches in the banking system, and real estate and stock market exposure.

\section{SuMmary AND KeY CONCLUSIONS}

Commercial banks in CEB countries are waking up. In some countries (the early birds), BCPS has been rising considerably faster than GDP for a few years, with the result that the BCPS ratio has increased at an average pace of some $2 \frac{1}{2}$ percentage points of GDP per year; in others (the late risers), the BCPS ratios has started rising only more recently; finally, in a third group of countries (the sleeping beauties), there is still no clear increase in the BCPS ratio, but credit to some sectors, notably to households, has accelerated sharply.

We find that the acceleration in BCPS and the differences across CEB countries reflect primarily overall financial deepening, the speed of privatization, crowding-in forces, and overall progress toward market institutions. Direct access of CEB banks to foreign interbank markets does not seem to have been a critical factor so far, even though CEB banks are mostly owned by foreign banks.

We believe that BCPS ratios will continue to rise rapidly in CEB countries in the years ahead as a result of both microeconomic and macroeconomic forces. Microeconomic forces include (i) privatization in 2001-2003 and further expected privatization in the years ahead; (ii) the attempt of CEB banks to raise profitability (currently low by European Union (EU) standards) by expanding the share of bank loans in total bank assets; and (iii) the improvement in accounting standards, risk-assessment techniques, availability of collateral, overall creditworthiness of potential borrowers, and - especially - in the protection of creditors' rights; all this should reduce the perceived risk of lending. As to macroeconomic forces, the growth of BCPS ratios should be facilitated by further fiscal consolidation, as CEB countries adjust to EU fiscal constraints and, especially, capital inflows. The latter are likely to strengthen as a result of declining risk premia as CEB countries enter the EU and

42 The same can be said for Estonia's aggregate BCPS ratio, which, in the past three years, grew at rates close or over 5 percent. 
approach participation in the euro area, in the context of nominal interest rate differentials that are still sizable in many countries; expectations of real appreciation; and overall scarcity of capital, with respect to labor, in the CEB area. In this respect, we also noted that the very growth of the banking market will likely attract capital inflows. Indeed, developments in some CEB countries - such as Croatia, where capital inflows recently strengthened in the absence of large interest rate differentials vis-à-vis the rest of the world and in the context of broad exchange rate stability - confirm that the profit opportunities arising for banks from an expanding credit market can be the driving force behind capital inflows, providing the liquidity necessary to fuel bank credit growth.

Reflecting these factors, BCPS ratios will move closer to their long-run equilibria. The latter was estimated in this paper by using the coefficient of an econometric model estimated using panel data from industrial and emerging markets. This model is more comprehensive (in terms of variables included) than previous models and also outperforms several other models in terms of overall fit. In its final specification, it links the BCPS ratio to per capita income; the public debt-to-GDP ratio; inflation; financial liberalization measures; and the legal, regulatory, and corporate culture of the country. When fitted to CEB countries, the model predicts BCPS levels well above the current ones, suggesting room for further increases.

At a macroeconomic level, the removal of microeconomic impediments to bank credit growth will have an expansionary effect on aggregate demand. Conceptually, it corresponds to a shift in the IS curve to the right. At the same time, assuming broad exchange rate stability, pressure from capital inflows will reduce the capability of central banks to control the money supply. Assuming the inefficacy of sterilized intervention in these circumstances, countries will have to use other instruments to avoid the risk of overheating if BCPS start rising too fast. Fiscal policy should play a critical role, and, in this respect, CEB countries are better positioned than, say, Asian countries were in the late 1990s to tighten fiscal policy. This is because further fiscal adjustment is needed in CEB countries also for structural reasons, so that structural and macroeconomic fiscal requirements would tend to coincide. The paper also discusses the role that, in the context of strong credit growth, can be played by administrative credit ceilings, controls on capital inflows, and enhanced prudential requirements. The latter are expected to play an important role, taking into account the need to also take care of the financial stability implications of fast bank credit growth.

The last part of our paper addressed the issues of whether BCPS growth in CEB countries has been "excessive" and whether it involved a credit boom that increased systemic bank risk. The preliminary answer is that, up to 2002, BCPS growth in CEB countries could hardly be compared, from a quantitative perspective, to the credit booms experienced in countries that were later hit by banking crises. Nevertheless, there are reasons to remain watchful. First, as noted, our tests are conditional on several caveats, mostly relating to the difficulty, for CEB countries, of distinguishing what is an "abnormal" growth of credit, since these countries have been in transition for several years rather than starting from a well-defined equilibrium. Second, overall credit developments may underestimate actual risks. More work would be needed to evaluate some important aspects of risk, such as currency risk, maturity mismatch, and sectoral risk (in particular, as it related to sectors exposed to asset-price bubbles). Third, 
we have observed faster bank credit growth in some subsectors of the economy, particularly the household sector, where more countries appear to have abnormally high increases in the BCPS ratio. Finally, as noted, in all likelihood there will be a further acceleration in BCPS growth in the CEB region, and country authorities will have to stand ready to assess its implications, including those for financial stability. Country authorities will have to stay ahead of the curve, making sure they have the capabilities of managing bank supervision within the context of a more complex and dynamic banking system. ${ }^{43}$

43 For a discussion of the key challenges for bank supervision in CEB countries, see Feldman and Wagner (2002) and Watson (2003). 


\section{DATa Description AND SourCes}

\section{A. BCPS and Other Bank Balance Sheet Data: CEB Countries}

Unless otherwise indicated below, all data on commercial banks' balance sheets were provided by IMF country desks, which, in turn derived them from official publications or received them directly from country authorities. The stock data are expressed in our paper as geometric averages of end-December data. The following table provides more detailed country information including on whether BCPS data include lending to state-owned enterprises (SOEs), or whether the latter is classified as lending to the government.

\begin{tabular}{|c|c|c|c|}
\hline Country & $\begin{array}{l}\text { Bank Credit to the } \\
\text { Private Sector }\end{array}$ & $\begin{array}{l}\text { Bank Credit to the } \\
\text { Public Sector }\end{array}$ & $\begin{array}{l}\text { Other Net } \\
\text { Liabilities }\end{array}$ \\
\hline Albania & $\begin{array}{l}\text { Excludes State Owned Enterprises } \\
\text { (SOEs) }\end{array}$ & Excludes SOEs & $\begin{array}{l}\text { Credit to SOEs is } \\
\text { included in other net } \\
\text { liabilities }\end{array}$ \\
\hline Bosnia & Excludes SOEs & Includes SOEs & \\
\hline Bulgaria & Excludes SOEs & Includes SOEs & \\
\hline \multirow[t]{7}{*}{ Croatia Ex } & cludes SOEs & Includes SOEs, through & \\
\hline & The BCPS series is the sum of lines & adding line $22 \mathrm{c}(\mathrm{DMB}$ & \\
\hline & $22 \mathrm{~d}$ (deposit money bank (DMB) credit & credit to non-financial & \\
\hline & to the private sector) and $22 \mathrm{~g}$ (DMB & public enterprises) to & \\
\hline & credit to non-bank financial & bank credit to the public & \\
\hline & institutions) from the International & sector & \\
\hline & Financial Statistics (IFS) of the IMF & & \\
\hline \multirow[t]{3}{*}{ Czech Republic } & Includes SOEs & & \\
\hline & $\begin{array}{l}\text { Available data did not have the level of } \\
\text { disaggregation necessary to exclude }\end{array}$ & & \\
\hline & SOEs & & \\
\hline \multirow{4}{*}{ Estonia Ex } & cludes SOEs & Includes SOEs & \\
\hline & $\begin{array}{l}\text { The BCPS series is a sum of IFS lines } \\
22 \mathrm{~d} \text { (DMB credit to the private sector) }\end{array}$ & & \\
\hline & and $22 \mathrm{~g}$ (DMB credit to non-bank & & \\
\hline & financial institutions), from IFS & & \\
\hline \multirow[t]{5}{*}{ Hungary E } & xcludes SOEs & Excludes SOEs & \\
\hline & The BCPS series is spliced: from 1993- & & \\
\hline & 97, the data series is line $22 \mathrm{~d}(\mathrm{DMB}$ & & \\
\hline & credit to the private sector); and from & & \\
\hline & $\begin{array}{l}1998-2002 \text {, data was provided by the } \\
\text { authorities }\end{array}$ & & \\
\hline Latvia & Excludes SOEs & Includes SOEs & \\
\hline Lithuania & Excludes SOEs & Includes SOEs & \\
\hline \multirow{3}{*}{$\begin{array}{l}\text { Macedonia, } \\
\text { FYR }\end{array}$} & Excludes SOEs & Includes SOEs & \\
\hline & The BCPS series is line $22 \mathrm{~d}(\mathrm{DMB}$ & & \\
\hline & credit to the private sector), from IFS & & \\
\hline \multirow{2}{*}{ Romania Ex } & cludes SOEs & Includes SOEs & \\
\hline & $\begin{array}{l}\text { The BCPS series is line } 22 \mathrm{~d} \text { (DMB } \\
\text { credit to the private sector), from IFS }\end{array}$ & & \\
\hline
\end{tabular}




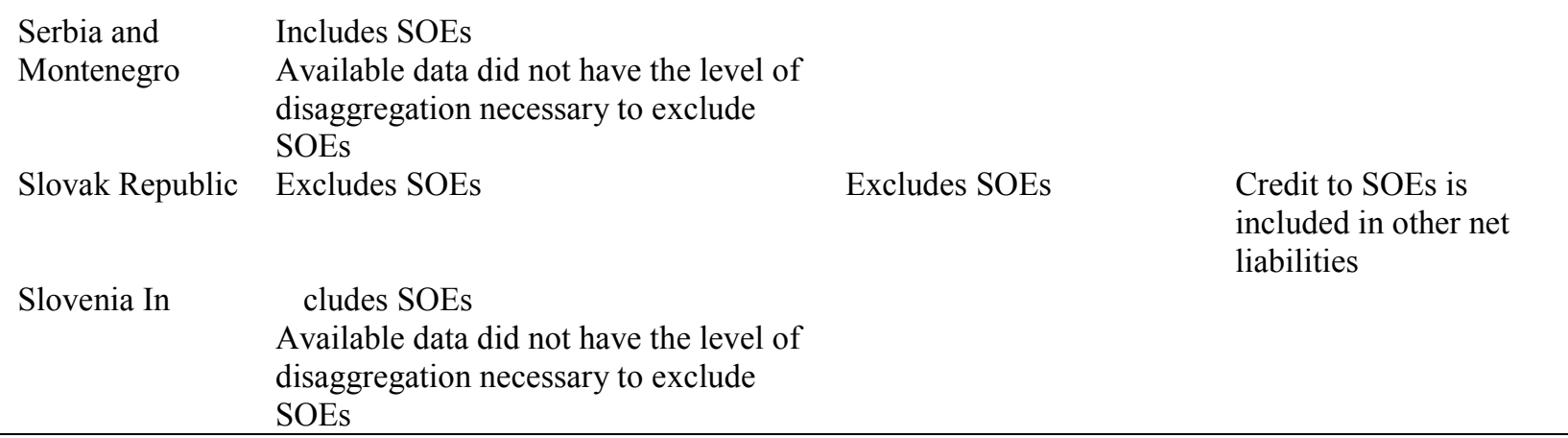

\section{B. Data Used to Estimate the Econometric Model}

BCPS: geometric averages of end-of-year data. Source: International Financial Statistics, line $22 \mathrm{~d}$.

Public Debt ratio: public debt (domestic plus external) as a share of GDP. Data from Lane and Milesi-Ferretti (2002).

GDP per capita: measured in U.S. dollars at PPP prices. Source: World Economic Outlook database

Inflation Rate: CPI-based inflation rate. Source: World Economic Outlook database

Liberalization Index: ${ }^{44}$ index, measuring the degree of liberalization across 6 dimensions: policies relating to directed credit, interest rate controls, entry barriers, regulation and securities markets, privatization in the financial sector, and international capital flows. Higher values of the index represent a greater degree of liberalization. The index are from Abiad and Mody (2003).

Accounting: ${ }^{45}$ Index created by examining and rating companies' 1990 annual reports on the inclusion or omission of 90 items in balance sheets and income statements. The maximum is 90 , the minimum is 0 . Greater values indicated greater comprehensiveness of company reports. Source: Table 5 in La Porta et al. (1998).

${ }^{44}$ This index does not cover CEB countries. For the purposes of out-of-sample prediction using the estimated coefficients from the non-transition sample, we construct this index using various data from the 2002 EBRD Progress in Transition report, which measures development relative to standards and policies in advanced industrial countries.

${ }^{45}$ This index does not cover CEB countries. For the purposes of out-of-sample prediction, we proxy this variable by taking the EU average of the accounting index to represent standards in advanced industrial countries, and the we use EBRD indexes of progress in financial regulations in the CEB countries to evaluate how far CEB countries are from that standard. 
Bank Entry Restrictions: An index of the various types of legal submissions required to obtain a banking license, used in Barth, Caprio, and Levine (2002). Greater values indicate greater stringency. This index is available at : http://www.worldbank.org/research/interest/ prr_stuff/bank regulation database.htmO

Legal Origin: Dummy variables for the origin of a country's legal tradition: German, French, British, or Scandinavian. Source: Appendix B in La Porta et al. (1999). 


\section{ECONOMETRIC MODEL: SPECIFICATION}

This appendix describes the specification on the econometric model of the BCPS ratio presented in Table 12. The model was estimated based on data for 24 countries, ${ }^{46}$ using annual data for 1973-1996, and a random effects GLS estimation procedure. The equation has the following form:

$$
\begin{aligned}
& \text { BCPS }_{i t}=\alpha_{0}+\alpha_{1} * \text { PubicDebtY } \\
& +\alpha{ }_{i t}+\alpha_{2} * \log (G D P P C)_{i t}+ \\
& +\alpha 5^{*} \text { LibIndex }_{i t}+\alpha 6 * \text { Accounting }_{i} \\
& ++\alpha 7 * \text { EntryRestrictions }_{i}+\alpha 8 * \text { German Legal Origin }_{i}+\varepsilon_{i t}
\end{aligned}
$$

where $B C P S_{i t}$ is bank credit to the private sector as a ratio to GDP (see below for the definition of other variables).

The random effect estimator was preferred to the fixed effect estimator given our interest in assessing the effect of a number of time-invariant variables. A Hausman specification test could not reject the hypothesis of no correlation between the errors and the regressor.

In selecting our set of explanatory variables we were guided by previous work on financial deepening, as well as various analytical arguments (see Appendix I for more detailed information on the definition of the variables).

PublicDebt $Y_{i t}$ is the ratio of the stock of public debt (domestic and external) to GDP. It has an expected negative sign, since it controls for the potential crowding out effect that credit to the public sector may have had on bank credit to the private sector. We find a fiscal stock variable (public debt) (more appropriate) than a fiscal flow variable (fiscal deficit or government expenditure, used in previous papers) since we are modeling the stock of private sector credit. ${ }^{47}$

$\log (G D P P C)_{i t}$ is the $\log$ of GDP per capita measured in PPP prices, and controls for the level of economic development. The expected sign is positive as we would expect a higher degree of financial deepening in high income countries, possibly because the latter are characterized by higher capital/labor ratio, and bank credit is a key source of external financing. The sign of this coefficient should, however, not be interpreted as involving causality, as we do not control for the possible effect of the degree of financial deepening on

${ }^{46}$ Argentina, Australia, Brazil, Canada, Chile, France, Germany, India, Israel, Italy, Japan, Korea, Malaysia, Mexico, New Zealand, Peru, the Philippines, Singapore, South Africa, Thailand, Turkey, the United Kingdom, the United States, and Venezuela.

47 Admittedly, domestic (rather than total) public debt would better proxy crowding out, but data availability constrained our choice. 
income levels. Rather, it reflects statistical correlation, the only aspect that is relevant for the purpose of assessing the "normal" level of the BCPS ratio.

High inflation is exacted to have a detrimental effect on financial deepening. ${ }^{48}$ In modeling this effect, we follow the non-linear threshold specification used by Khan, Senhadji, and Smith (2001). They find that for rates of inflation below the threshold, small increases have either no effect or a small positive effect on the level of financial activity, and that the threshold level beyond which inflation significantly affects financial deepening is in the

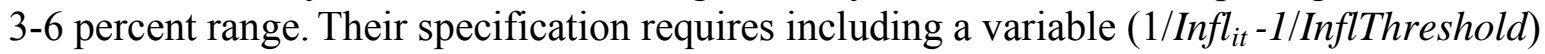
measuring how far below or above the threshold the level of inflation is at time $t$ for country $i$, and a second variable(HighInfl), which is a dummy for inflation above the threshold level. Based on Khan, Senhadji, and Smith (2001) the threshold was set at 4 percent, although, in principle it could have been estimated through a scanning procedure.

LibIndex $_{i t}$ is an index of financial liberalization of both the domestic financial system and of the capital account. The literature on the positive effect that domestic financial liberalization could have on financial development dates back to McKinnon (1973) and Shaw (1973). The role of capital account liberalization has also been explored. The argument is that open capital flows facilitate the import of financial services, and increase competition and the efficiency of the financial system. Studies examining the empirical link between capital account liberalization and financial depth (Klein and Olivei, 1999) have shown the relationship to be most robust for developed countries. Although liberalization episodes are often blamed for subsequent financial crises, Williamson and Mahar (1998) survey evidence of the direction of the relationship between liberalization and financial deepening and conclude that the relationship is fairly robust and positive over the long run.

We also included an index of liberalization more specifically related to the banking sector. Following work by Barth, et al (2002), we include a measure of bank regulation, Entry Restrictions $_{i}$, which measures the stringency of specific legal requirements for obtaining a license to operate as a bank. ${ }^{49}$

${ }^{48}$ Alternatively, one could argue that it is the variability of inflation rather than its level that affects nominal contracts and financial deepening. This problem was recognized by Boyd, Lovine, and Smith (1996), who noted that it is impossible to disentangle the two hypotheses, as, at least in their sample, the simple correlation between inflation and its standard deviation is 0.97 .

${ }^{49}$ A number of other regulatory and institutional variables should also have been included, in principle, such as the availability of public and/or private credit information bureaus (Miller, 2003). Barth, Caprio, and Levine (2002) conduct a comprehensive study of the effect of bank regulation (capital requirements, private monitoring, official supervisory power, entry restrictions into banking, restrictions on types of activities that banks can engage in, among others) and find that excessive government supervision and regulation of bank activities has a negative impact on bank development. Barth et al (2002) find that an index of Private 
Accounting is an index of accounting standards, included to control for the quality of information on which lending decisions are based. More information is expected to facilitate financial deepening, as it reduces the risk premium vis-à-vis risk-free assets.

The legal origin of a country has been shown to have a significant effect on financial deepening, even when controlling for GDP per capita, and a number of other variables (see for example, Beck, Demirgüç-Kunt, and Levine (2001)). The effect of legal origin on financial development is hypothesized to run through both the type of individual rights it fosters and protects (law and finance theory), and through its ability to change and adapt to commercial needs (dynamic law and finance theory). In particular, the literature has shown that German civil law systems tend to have stronger protection of private property, effective contract enforcement, and well-developed banks, partly due to the flexibility of German commercial law, as German legal scholars explicitly sought to make their legal system more adaptable than the French system. Hence, German Legal Origin is a dummy variable which identifies those countries whose laws can be traced to the German legal tradition. ${ }^{50}$

Finally, we also included a number of dummies controlling for breaks in the BCPS ratio series. The dating of the breaks in the series is derived from country pages in the IMF's International Financial Statistics.

The estimated equation is reported in Table 12. With an R-squared of 0.66 , its fit is quite good compared both with previous attempts to estimate BCPS ratio equations and a fixed effect estimator that excluded all time-invariant variables. ${ }^{51}$ The estimate of the coefficient, and, thus, the "equilibrium level' of BCPS ratios for CEB countries, which were derived through out-of-sample projections, were also quite robust to alternative specifications. While

Monitoring (summarizing information on audit requirements, deposit insurance schemes, bank accounting and disclosure practices and capital requirements) is a significant factor in explaining bank development. Using these variables, however, would have significantly restricted our sample due to data unavailability.

${ }^{50}$ Other dummy variables for French and British legal systems were also included but appeared not to be significant.

${ }^{51}$ The R-squared from a fixed effect estimation of the same model, but excluding the timeinvariant variables was 0.47. Comparing the fit of our model with previous work is difficult as the country and time series sample, as well as the time frequency, is different. Based on an R-squared comparison, our fit seems to be better. The model in Khan, Senhadji, and Smith (2001) using the BCPS ratio as a dependent variable, has an R-squared of 0.52 . The model in Boyd, Levine, and Smith (1996) has an R-squared between 0.48 and 0.50, depending on how threshold inflation is defined. The annual model in Levine, Loayza, and Beck (2000) has an R-squared 0.55 . 
these can be obtained from the authors, we just report here one alternative specification, which employs a different formulation for the non-linear effect of inflation (text table).

Econometric Model of the BCPS Ratio

Random Effects Panel Regression, Nontransition Countries, 1973-96, Alternative Inflation Specification

\begin{tabular}{lcccc}
\hline & Coefficient & Standard Error & t-statistic & \\
\hline Public debt / GDP & -0.164 & 0.032 & -5.11 & ${ }^{* * *}$ \\
Log (GDP per capita) & 0.094 & 0.024 & 4.02 & ${ }^{* * *}$ \\
Inflation rate & -0.843 & 0.141 & -5.98 & ${ }^{* * *}$ \\
High-inflation dummy & -0.064 & 0.017 & -3.71 & ${ }^{* * *}$ \\
High-inflation dummy * Inflation rate & 0.843 & 0.141 & 5.98 & ${ }^{* * *}$ \\
Liberalization index & 0.189 & 0.034 & 5.56 & ${ }^{* * *}$ \\
Bank entry requirements & -0.031 & 0.027 & -1.15 & \\
Accounting & 0.008 & 0.003 & 2.68 & ${ }^{* * *}$ \\
German legal origin & 0.266 & 0.105 & 2.54 & ${ }^{* *}$ \\
Trend 0.003 & & 0.002 & 1.44 & \\
Constant - & 0.759 & 0.290 & -2.62 & \\
Number of observations & 471 & & & \\
R-squared 0.61 & & & & \\
\hline
\end{tabular}

Source: Appendix I.

Note: $* * *$, and $* * *$ denote significance at 10,5 , and 1 percent levels, respectively.

Following Boyd, Levine, and Smith (1996), the non-linear effect of inflation is modeled through the inclusion of a high inflation dummy which takes the value of 1 when inflation is above the threshold, and an interaction term of inflation with the high inflation dummy, the coefficient of which, when summed with the coefficient on the inflation term, gives the response of BCPS ratio to increases in inflation above the threshold. This specification is estimated using an inflation threshold of 15 percent, although results are broadly robust to the choice of threshold.

The signs and magnitudes of the inflation effects are in line with the findings in Boyd, Levine and Smith (1996). As in the latter, however, these coefficients imply awkward dynamics of the BCPS ratio in response to inflation dynamics: at an inflation rate of 15 percent, just at the threshold, the negative contribution of inflation to the BCPS ratiorising up to that point - is 13 percentage points. However, once inflation exceeds the threshold, the negative contribution of inflation drops to 6 percentage points and remains constant at that level thereafter. We thus preferred the specification in Table 12. As noted, however, similar equilibrium levels for the BCPS ratio were obtained also with the specification in the text table. 


\section{REFERENCES}

Abiad, Abdul, and Ashoka Mody, 2003, "Financial Reform: What Shakes It? What Shapes tP," IMF Working Paper 03/70.

Barabás, Gyula, István Hamecz, and Judit Neményi, 1999, "Fiscal Consolidation, Public Debt Containment and Disinflation," NBH Working Paper 1998/5 (May).

Barth, R. James, Gerard Caprio, and Ross Levine, 2002, "Bank Regulation and Supervision: What Works Best?", Journal of Financial Intermediation, National Bureau of Economic Research, Working Papers Series (U.S.) No. 9323: pp. 1-46. (November).

Beck, Thorsten, Aslí Demirgüç-Kunt, and Ross Levine, 2001, "Law, Politics, and Finance," World Bank, Working Paper 2585

, Ross Levine, and Norman Loayza, 2000, "Finance and the Sources of Growth," Journal of Financial Economics 58, pp. 261-300.

Begg, David, 1998, "Pegging Out: Lessons From the Czech Exchange Rate Crisis," Centre for Economic Policy Research, Discussions Papers Series No. 1956, International Macroeconomics and Transition Economies, (September), London.

Boyd, John, Ross Levine, and Bruce Smith, 1996, "Inflation and Financial Market Performance,” Federal Reserve Bank of Minneapolis, Working Paper 573D.

Calza, A., C. Gartner, and J. Sousa, 2003, "Modelling the Demand for Loans to the Private Sector in the Euro Area, Applied Economics, 35, pp. 107-117.

Christensen, Jakob, 2003, Capital Inflows, Sterilization, and Private Bank Speculation: The Case of the Czech Republic, IMF unpublished.

Cottarelli, Carlo, Giampaolo Galli, Paolo Marullo Reedtz and Giovanni Pittaluga, 1986, “Monetary Policy Through Ceilings on Bank Lending," Economic Policy (October).

Dell'Ariccia, Giovanni, and Robert Marquez, 2003, "Lending Standards and Banking Crises," IMF unpublished.

Demirgüç-Kunt, Aslí, and Enrica Detragiache, 1997, “The Determinants of Banking Crises: Evidence from Developing and Developed Countries", World Bank Working Paper No. 1828.

Drees, Burkhard, and Ceyla Pazarbaşioğlu, 1998, “The Nordic Banking Crises-Pitfalls in Financial Liberalization?” IMF Occasional Paper 161 (Washington, International Monetary Fund). 
European Bank for Reconstruction and Development (EBRD), 2002, Transition ReportAgriculture and Rural Transition, Economic Transition in Central and Eastern Europe and the CIS.

Feldman, Robert A., and Nancy L. Wagner, 2002, "The Financial Sector in Central Europe: Interlinkages with Macroeconomic Policy and Performance on the Road to the EU," paper presented at the 2002 EIB Conference on Economics \& Finance, January 17, 2002, Luxemburg.

Fernández-Ansola, Juan, and Reza Moghadam, Capital Flows, 1996, "Reverse Currency Substitution, and Sterilized Intervention," IMF unpublished.

Ghosh, Atish, Timothy Lane, Marianne Schulze-Ghattas, Aleš Buliř, Javier Hammann, and Alex Mourmouras, 2002, " IMF-Supported Programs in Capital Account Crises," IMF Occasional Paper 210, (Washington, International Monetary Fund).

Goldfajn, Ilan, and Rodrigo O. Valdés, 1997, "Capital Flows and the Twin Crises: The Role of Liquidity,” IMF Working Paper /97/87 (Washington: International Monetary Fund).

Gourinchas, Pierre-Olivier, Rodrigo Valdes, and Oscar Landerretche, 1999, "Lending Booms: Some Stylized Facts," (October). , 2001, "Lending Booms: Latin America and the World," Economia, pp. 47-99

( $\mathrm{S} \quad$ pring). Italy.

Hardy, Daniel C., and Ceyla Pazarbasioglu, 1991, "Leading Indicators of Banking Crises: Was Asia Different?” IMF Working Paper 98/91 (Washington, International Monetary Fund).

Kaminsky, Graciela L., and Carmen M. Reinhart, 1999, "The Twin Crises: The Causes of Banking and Balance-of-Payments Problems," American Economic Review, Vv89, N.3, pp. 473-500

Khan, Mohsin, Abdelhak Senhadji, and Bruce Smith, 2001, "Inflation and Financial Depth," IMF Working Paper 01/44 (Washington, International Monetary Fund).

Kiss, Gergely, 2002, "The Housing Market and Financial Stability in the Light of EU Accession, National Bank of Hungary, Report on Financial Stability (December).

Kiyotaki, Nobuhiro, and John Moore, 1997, “ Credit Cycles,” Journal of Political Economy, Vol. 105, No. 2, The University of Chicago Press, pp. 211-248 (April). 
Klein, Michael and Giovanni Olivei, 1999, "Capital Account Liberalization, Financial Depth, and Economic Growth", NBER Working Paper 7384.

Köke, Jens, and Michael Schröder, 2002, "The Prospects of Capital Markets in Central and Eastern Europe,” Discussion paper No. 02-57, Center for European Economic Research.

Lane, Philip R., and Gian Maria Milesi-Ferretti, 2002, "Long-Term Capital Movements," NBER Macroeconomic Annual 2001, edited by B. Bernanke and K. Rogoff, Cambridge, MA: MIT Press.

La Porta, Rafael, Florencio Lopez-de-Silanes, Andrei Schleifer, and Robert Vishny, 1998, "Law and Finance," Journal of Political Economy, Vol. 106, p.1113. , 1999, "Quality of Government," Journal of Law, Economics and Organization, Vol. 15 (1), pp 222-279

Levine, Ross, Norman Loyaza, and Thorsten Beck (2000), "Financial Intermediation and Growth: Causality and Causes," Journal of Monetary Economics, Vol 46 pp. 31-77.

Lipschitz, Leslie, Timothy Lane, and Alex Mourmouras, 2002, "Capital Inflows to Transition Economies: Master or Servant?” IMF Working Paper 02/11 (Washington, International Monetary Fund).

McKinnon, Ronald, 1973, Money and Capital in Economic Development, Washington, Brookings Institution

Miller, Margaret, ed., 2003, Credit Reporting Systems and the International Economy, MIT Press, Cambridge, Mass.

Neményi, J. 1996, "Capital Inflow, Macroeconomic Equilibrium, the Public Debt and the Profit and Loss of the National Bank of Hungary," Acta Oeconomica, periodical of the Hungarian Academy of Sciences, Vol. 48 (3-4), pp. 241-270.

Organization for Economic Cooperation and Development, 1996, OECD Economic Surveys, The Czech Republic, OECD Publications, Paris, France.

Pissarides, Francesca, 2001, "Financial Structures to Promote Private Sector Development in South-Eastern Europe," European Bank for Reconstruction and Development Working Paper No. 64 (June), London.

Rajan, Raghuram G. and Luigi Zingales, (1998), "Financial Dependence and Growth," American Economic Review, Vol. 88, Number 3, pp. 559-586 (June). 
Riess, Arman, Rien Wagenvoort, and Peter Zajc, 2002, "Practice Makes Perfect: A Review of Banking in Central and Eastern Europe,” EIB Papers, Vol 7. No. 1, pp. 31-53.

Schadler, Susan, Paulo Drummond, Louis Kuijs, Suzana Murgasova, and Rachel van Elkan, 2003, "Adopting the Euro in Central Europe: an Examination of Policy Issues, IMF Occasional Paper, forthcoming.

Shaw, Edward, 1973, Financial Deepening in Economic Development, New York, Oxford University Press.

Thimann, Christian (ed), 2002, "Financial Sectors in EU Accession Countries," European Central Bank, Frankfurt.

Watson, C. Maxwell, 2003, "Financial Sector Efficiency in the EU Accession Countries of Central and Eastern Europe (CEE): The Impact of Policies and the Road Ahead," paper presented at the $24^{\text {th }}$ SUERF Colloquium, June 12-14, Tallinn.

Williamson, John and Molly Mahar, 1998, “A Survey of Financial Liberalization,” Essays in International Finance, Nov. 1998, Princeton University. 